UC-NRLF

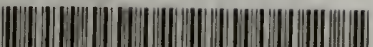

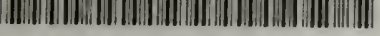

B 4 리 ㄹㅋ 


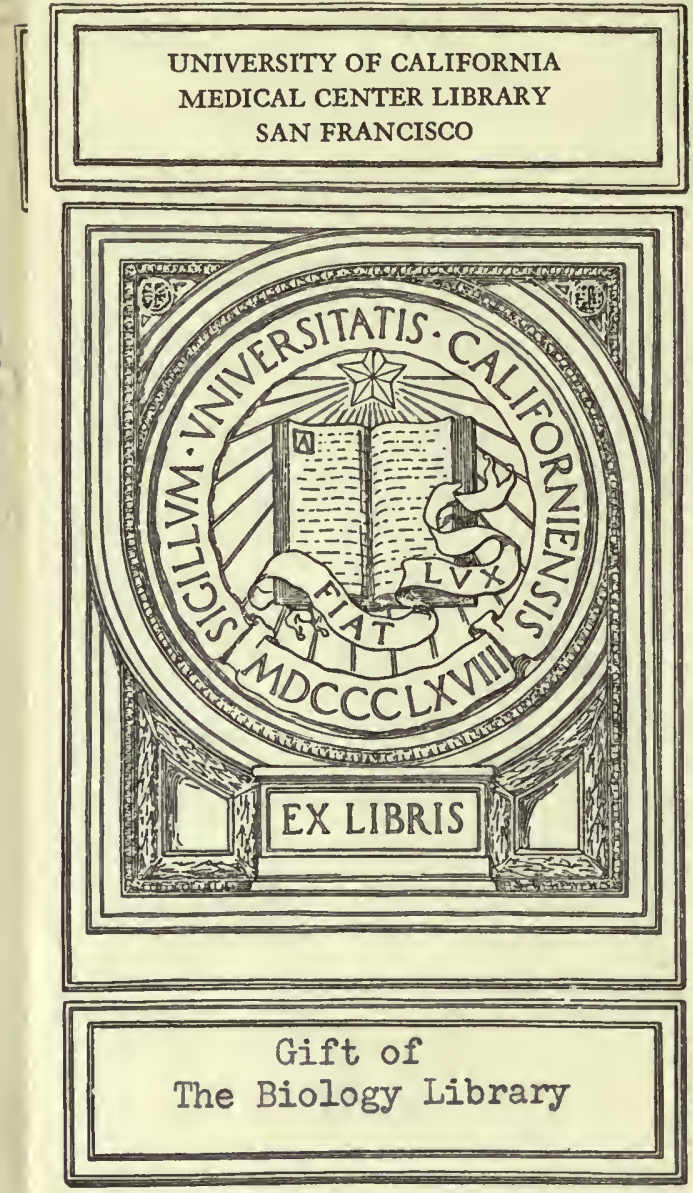



Digitized by the Internet Archive in 2007 with funding from Microsoft Corporation 


A Bacteriologic Study of the Diphtheroid Organisms with Special Reference to Hodgkin's Disease

\section{DISSERTATION}

Submitted in Partial Fulfilment of the Requirements for the Degree of Doctor of Philosophy in the Faculty of Pure Science of Columbia University in the City of New York

BY

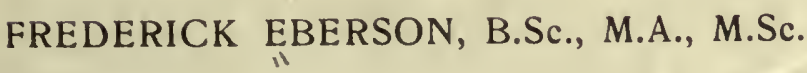

NEW YORK CITY

1918 



\section{PREFACE}

The study reported in the following pages was undertaken with the purpose of sifting out the voluminous data which have accumulated on the subject of diphtheroid organisms.

The greatest impetus given to such an investigation has resulted, in recent years, from the attempts of numerous workers to associate Hodgkin's disease with a certain organism belonging to the diphtheroid group. In a short time the literature on the subject assumed great proportions.

A survey of the field revealed immediately the fact that the group as a whole has been indiscriminately used as a cover for any organism which bore some sort of morphological resemblance, real or apparent, to the diphtheria type. The material presented in this study is by no means exhaustive since a great many methods will have to be tried before a clear-cut answer is to be given to the question as tc what a true diphtheroid is and where it belongs in the comprehensive group of which these bacteria are members.

Of great moment is the idea of mutation introduced by Rosenow and his school. This problem is fraught with such difficulties not amenable to satisfactory control, that a reply to the findings of these workers will have to be deferred. At present the outlook for a decisive answer to this question seems to be found in at least one method whereby we can control the constitution of our nutrient media by means of $\mathrm{H}$-ion concentration, and also in a plase of serological technic which has not been studied heretofore. In the following pages an effort will be made to attack the problem from these angles.

I wish to thank Professor Hans Zinsser for much valuable advice and suggestions and Dr. R. E. Buchanan of the Iowa State College for his criticisms on nomenclature.

F. E.

Bacteriological Laboratory, Columbia University.

New York City, January, 1918. 



\section{CONTENTS}

Preface

1. NOMENCLATURE AND CLASSIFICATION OF THE DIPHTHEROIDS

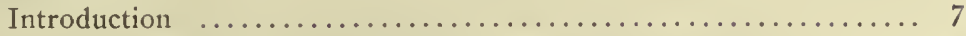

HISTORICAL REVIEW OF DIPHTHEROIDS AND EMENDATIONS......... 8

DISTRIBUTION OF DIPHTHEROIDS...................... 18

Diphtheroids in Hodgkin's Disease................... 18

Diphtheroids in Glands and Tissues.................... 18

Cultural Study and Grouping of Organisms..........18, 19

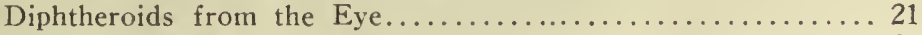

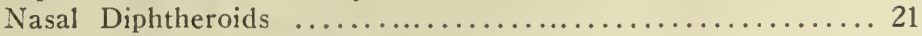

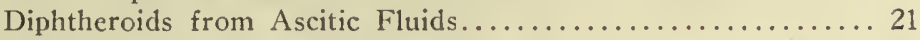

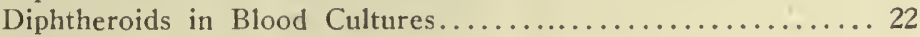

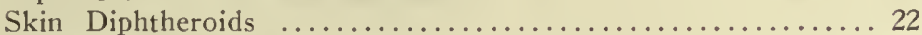

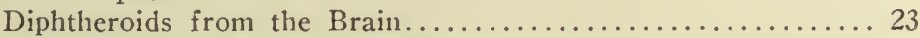

Diphtheroids from the Appendix................... 23

Source and Fermentative Reactions...................24

CLASSIFICATION OF THE DIPHTHEROIDS.................. 25

2. SEROLOGIC STUDY

EXPERIMENT WITH HODGKIN'S STRAINS................. 30

Agglutination Tests ............................. 31

Complement Fixation ........................... 31

APPLICATION OF AGGLUTININ ABSORPTION TESTS TO DIFFERENTIATION

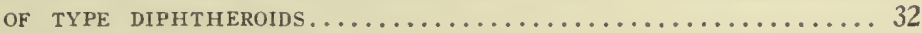

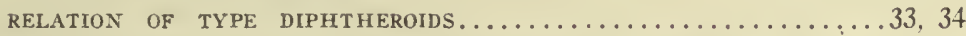

3. PLEOMORPHISM OF DIPHTHEROIDS, MUTABILITY OF TYPES AND A METHOD FOR DETERMINING MUTANTS

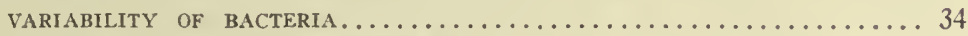

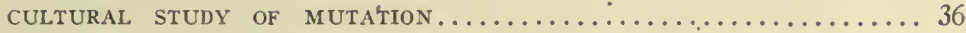

Experiments with Museum Strain of C. enzymicus (Mellon)... 36

Effect of Various Mediums on Selection of Type......... 37

Experiments with Mellon Strain cultivated on Blood Medium. 39 STUDY WITH PURE LINE OF C. ENZYMICUS ................. 39

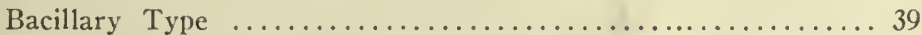

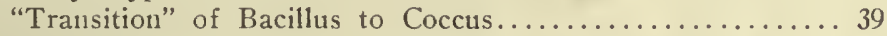

Coccus Type .............................4 40

Behavior of Coccus and Bacillary Types in Carbohydrates..... 41

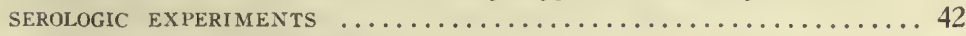

Absorption of Agglutinins...................... 42

Absorption Experiments with Coccus Serum............ 42

Absorption Experiments with Bacillary Serum.......... 43

SUMMARY AND CONCLUSIONS............................ 44

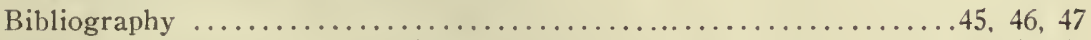

Plates 1-3. Explanation of plates...................48,49, 51, 53

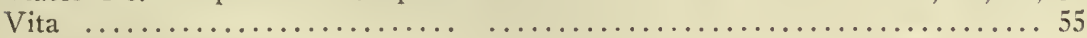





\title{
A BACTERIOLOGIC STUDY OF THE DIPHTHEROID ORGANISMS WITH SPECIAL REFERENCE TO HODGKIN'S DISEASE
}

\author{
Plates 1-3 \\ FREDERICK EBERSON
}

From the Department of Bacteriology, Columbia University, College of Physicians and Sur. geons, New York City

\section{NOMENCLATURE AND CLASSIFICATION OF THE DIPHTHEROIDS}

\section{INTRODUCTION}

Within the past few years the literature dealing with organisms of the diphtheria group have received many new contributions. It seems that most human and animal diseases of hitherto unknown etiology have been ascribed to some sort of diphtheroid organism. Whether or not these results will be confirmed has little bearing on the problem which confronts the systematic bacteriologist who finds himself hard put to it in attempting to classify the great number of organisms which for no reason other than a slight resemblance to the diphtheria bacteria have been thrown haphazardly into a group of "unknowns"-the diphtheroids.

Since Loeffler's discovery of the diphtheria organism, so many so-called "pseudodiphtheria" bacteria have been mentioned in the literature that it seems necessary at this time to survey the field and come to an understanding as to what constitutes a diphtheroid.

In a recent paper on the "Nomenclature of the Coccaceac," Buchanan has pointed out the chatic state of bacterial nomenclaturc. That the naming of species, genera and higher groups needs careiul study and revision is a foregone conclusion. A great need is felt for such an analysis in the groups of bacteria which possess common characteristics. Such a group is the diphtheroid group.

First, it is necessary to define a "diphtheroid." The term "pseudodiphtheria" has always seemed unsatisfactory because the organisms so-called differ in so many respects from the true Klebs-Loeffler organism as to warrant the dropping of the term from the literature except in conditions to be suggested herewith. A review of the extensive 
work done in this group reveals the fact that there are bacteria which resemble the true diphtheria organism morphologically and culturally, but which differ in one important respect, namely, that of virulence as tested on guinea-pigs. The true Klebs-Loeffler has been shown to ferment dextrose, maltose and dextrin with acid production and to possess definite toxic properties on injection, resulting in the death of the animal in 3-4 days with a characteristic inflammation and congestion of the suprarenal glands. To those bacteria which lack this virulence but which otherwise conform to the character of true diphtheria bacteria, should be assigned the species designation "pseudodiphtheria." The generic name given to the group by Lehmann and lteumann is Corynebacterium and should be retained for the organisms of this group. Certain characters ought to be accepted as properly belonging to the species before we can adequately define what we mean by a diphtheroid. These may be enumerated as follows: Morphological resemblance to diphtheria organism, gram-positive, nonmotile, absence of spores, presence or absence of metachromatic granules, no gas-production in carbohydrate mediums. The fermentation of sugars may or may not occur. This property gives us a basis for classification which will be taken up later. A careful study of the different species which have been described shows that the characters enumerated ought rightly to be accepted as a basis for differentiating the diphtheroids from other bacteria which have been improperly classed with them. With this end in view the different species are taken up individually and examined from the standpoint of validity and priority. The suitability of the name is considered from the viewpoint of sufficient description, and in the light of more comprehensive studies which have given us suggestions for proper nomenclature. When the species name implies etiology which is unknown, doubtful or unconfirmed, that part of it is modified to suit the case.

\section{Historical Review of Diphtheroids and Emendations}

\section{B. pseudodiphtheriticum (Loeffler) Migula}

The description is given as follows: Gram-positive, no polar bodies, nonmotile. Grows luxuriantly on blood serum with a glistening layer. In broth clouding is produced. Loeffler described a pseudodiphtheria organism in his first paper on the etiology of diphtheria. He said the organism resembled diphtheria but was avirulent for guinea-pigs; that it was smaller than the true diphtheria and showed a marked absence of club-shaped forms. In 1888, v. Hofmann published an account of avirulent diphtheria-like organisms isolated from the oral cavity in 26 of 45 normal persons. He called these organisms pseudodiphtheria bacilli and described them as follows: Clouding produced in broth, no acid production, grow at room temperature, no spores. 
The rightful name for this species is Corynebacterium pseudodiphtheriticum (Hofmann-Wellenhof). It is questionable, however, if we can retain this name for all diphtheroids which are morphologically and culturally like the one described by v. Hofmann. Recent studies show that there are different species of saprophytic diphtheroids which conform to the type characters, yet are not found in the nose or throat. At the close of this communication we shall describe a few such strains which have been isolated from widely varying sources.

\section{B. PSEUDODIPHTHERITICUS ALCALIFACIENS \\ B. PSEUDODIPHTHERITICUS ACIDUM FACIENS}

These names were applied by Kurth to diphtheroid organisms which he found to be avirulent, and were capable of producing, respectively, a weakly alkaline and an acid reaction in sugar broth. The alcalifaciens species conforms to the following description: No granules, short forms on serum with white growth, abundant growth in bouillon with clouding, no acid produced in sugar broth.

This description, although meager, suggests that Kurth was undoubtedly dealing with the type Hofmanni. B. alcalifaciens should lapse into synonymy with this species. As for the B. pseud. acidum faciens a new species is hardly justified in view of the fact that avirulent diphtheroids differ in their fermentative properties in various sugars. Moreover the description is incomplete. Apart from the interest which attaches to the first attempt at classifrcation from the fermentation standpoint, these two species have no particular value.

\section{B. XEROSIS (NEISSER AND KUSCHBERT) MIGULA}

Club-shaped, plump, and longer septate forms. On blood serum terminal swellings never noted. Gram-positive, polar bodies sometimes visible, no growth below $25 \mathrm{C}$., no clouding in bouillon, but granular sediment is formed. Distinguished from pseudodiphtheria by its ability to grow only above $25 \mathrm{C}$.

One point needs slight modification in this description of B. xerosis, namely, that of temperature requirement. On certain mediums, such as ascitic dextrose agar we have noted growth of 12 strains of diphtheroids which were isolated fiom the eye. These organisms complied with the description given for B. xerosis as regards morphology and fermentative properties in different carbohydrate broths. Some of the strains developed very slowly at temperatures ranging from 18-25 C., showing delicate growth on slant mediums after 4 days. Eisenberg states that B. xerosis grows only at body temperature.

\section{B. SEPTATUM GELPKE}

Nonmotile, gram-positive, club-shaped forms on serum. Young cultures show polar staining, no spores. Grows on serum with a delicate yellowish dry appearance. In bouillon no clouding occurs but a granular flaky deposit is visible. Does not grow at temperatures below $28 \mathrm{C}$. Is to be distinguished from other organisms of the group by this property. Associated with conjunctival inflammation-"schwellungskatarrh."

A comparison of the 2 organisms just described makes it appear questionable that we are dealing with a distinct species in B. septatum. This organism which appears to be identical with B. xerosis is, like the latter, not necessarily àssociated with a conjunctivitis for $\mathrm{B}$. xerosis has been isolated frequently from normal eyes. Zinsser is of the opinion that the B. xerosis is a harmless parasite which may occur more often in the slightly inflamed than in the normal conjunctiva. The term septatum is not especially characteristic for diph- 
theroids associated with normal and diseased eyes. Large striped or septate bacteria have been found in the nose and in the blood during the course of personal study on this group of organisms.

\section{B. NODOSUS PARVUS (LUSTGARTEN-MANNABERG)}

Club-shaped organism, disposed at angles or parallel nonmotile, spores absent, slow growth at $37 \mathrm{C}$. on agar with white appearance, nonpathogenic, facultative. Found in normal human urethra. Migula has changed the name of this bacterium somewhat and calls it B. nodosum. Similar organisms have been isolated from the urine. In one case we have found this organism associated with a gonorrheal urethritis and in another instance in normal urine. Marked differences have been noted in the acid-forming properties of these 2 strains. One gives rise to abundant acid in several sugars and the other fails to attack any of them. They are gram-positive. Hine mentions 11 strains of diphtheroids which he isolated from the urogenital tract. They appeared as large clubbed forms, markedly segmented and exhibited granules, often of large size. They fermented dextrose, saccharose, maltose and dextrin.

It is suggested that the name Corynebact. nodosum (Migula) be given to these organisms and that $\mathrm{B}$. nodosum parvum lapse into synonymy.

\section{B. ENDOCARDITIS GRISEUS (WEICH SELBAUM)}

Flügge classifies this species under the head of pseudodiphtheria. It is a short rod, morphologically resembling B. xerosis. Grows well at room temperature, facultative, gram-positive, irregular staining property, is actively motile, glistening growth on mediums, with grayish-white appearance. In streak cultures a light brown or. reddish-gray growth is observed. Pathogenic for guinea-pigs and white mice. Rabbits, when injected, show endocarditis. Found on the heart valves in a fatal case of recurrent ulcerative endocarditis. According to the suggested definition for diphtheroid this bacillus should be ruled out. The property of motility has not been observed among members of the diphtheria group.

\section{B. ERYTHEMATIS}

Demme, in 1887, described an organism which caused erythema with death in guinea-pigs. It is a delicate rod, disposed in smaller or larger groups, nonmotile, forms spores, grows best at $37 \mathrm{C}$. but is slow in development, facultative, gram-positive. Flügge has put this bacterium in the diphtheroid group. Apart from the diphtheroid picture which might be seen in a microscopic field because of the configuration in groups and by virtue of the bulging forms due to spores, there is no apparent reason for classifying this species as a diphtheroid. Sporeformation rules the organism out of the group.

\section{B. RENALIS BOVIS (ENDERLEN) MIGULA}

Rods with thickened ends, nonmotile, gram-positive. In broth, a granular precipitate is formed, the mediums remaining clear. Obligate aerobe. Does not grow at room temperature. A more adequate description is given by Ernst. $\mathrm{He}$ isolated the strain from cases of pyelonephritis in cattle. The organism grows poorly as compared with the diphtheria bacterium. Babes-Ernst granules appear much later. It is club-shaped, lancetlike or cylindrical. No growth takes place at room temperature. No acid produced in dextrose and glycerin, no spores, facultative aerobe, nonmotile, gram-positive. Pathogenicity appears doubtful. Ernst was unable to demonstrate virulence for guinea-pigs or rab- 
bits by means of intraperitoneal or intrapulmonary inoculations. Concludes that the organism is not etiologic for pyelonephritis, since he could not recover the organism from the lesions or reproduce the disease.

Grips named an organism which he isolated from swine Bacillus pyogenes - suis. Künnemann described a similar organism from cattle under the name B. pyogenes bovis. Glage combined the two under the single specific name B. pyogenes. Glage and Prieve, in their studies have shown that the organisms are related to the influenza bacillus and are members of the group of hemoglobinophilic organisms. The name C. pyogenes (Glage) is perhaps most suitable for this organism.

Among human beings, pus cavities and suppurating wounds have been found to harbor diphtheroid organisms. Whether or not these possess pyogenic properties is speculative. It may be of interest to note that three strains isolated by the writer have been obtained from an anal pus pocket in a patient whose kidney underwent suppuration and complete necrosis. These organisms have been injected subcutaneously and intraperitoneally into guinea-pigs with negative results. Diphtheroids found in sinuses following abscess formation are not rare. It is very likely that these organisms are skin inhabitants.

\section{B. STRIATUS FLAVUS (V. BESSER)}

Eisenberg's description: Found in normal nasal mucus. Short thick rods, sometimes curved, with striped or barred appearance. On agar, white, thick growth with yellow pigment. Grows rapidly at room temperature, no spores.

\section{B. STRTATUS ALbUS (V. BESSER)}

Same source as B. striatus flavius. Appearance the same. Growth on agar is white and glistening, no spores. Flügge mentions B. striatus albus only. Chester has named the organism B. striatum.

That these striped diphtheroids occur in the normal nasal mucus has been shown by several investigators. Undoubtedly v. Besser was dealing with but one type of organism which is capable of producing pigment varying from white to yellow. In a comprehensive study made by Morse this was found to be the case. Our own studies have confirmed these findings. Morse has given this species diphtheroid the name $B$. flavidus with the following diagnosis: Thick forms with clear cut bars. Large and irregular granules visible. Heavy growth on serum with pigment varying in color from white to yellow. Ferments dextrose and maltose but not saccharose. B. flavidus as a species designation is invalid since a prior description had already been given by $\mathrm{v}$. Besser and later amended by Chester to conform with binomial system of nomenclature. The emendation by Morse is recognized but the species should be written, Coryn. striatum (Chester) nov. comb.

\section{B. BORDONI-UFFREDUZZI (EISENBERG)}

This is known as B. epidermidis and has been described as Bizzozeros Leptothrix epidermidis. It is an avirulent spore-former growing best at 15-20 C. Since this organism does not conform to the genus requirements, it should not be classed with the diphtheroids.

\section{B. Clavatus}

Flügge, in 1894, gave this name to a club-shaped bacillus which he isolated from milk heated to $100 \mathrm{C}$. for one hour. It is a long bacillus, motile, forms spores. Swollen at ends, anaerobic, liquefies gelatin. 
This same species is met with in an earlier work on dysentery by Kruse and Pasquale. They isolated from the heart blood and mesenteric fluid in ases of Egyptian dysentery an organism which they call "B. clavatus." It is not described in any way as to warrant its recognition as a species. The characters enumerated by Flügge make it invalid as a type of corynebacteria.

\section{SPORE-FORMING DIPHTHEROID OF DE SIMONI}

Isolated from nasal secretion in case of ozena. Said to form spores only when grown in milk or on potato. Facultative anaerobe. Grows luxuriantly in dextrose, lactose and maltose broth with slight acid formation.

The author was undoubtedly misled by the appearance of an impure culture. The illustration given in his article shows a complete transformation from a typical diphtheroid of slender and unevenly staining aspect to a blunt sporebearing rod in older cultures. This is highly improbable, yet were it absolutely authentic, one should not be inclined to class this species with the diphtheria group for reasons outlined previously.

\section{B. DIPHTHEROIDES}

Described by Klein. Isolated from purulent secretion of udder of cow. Organism fails to grow below $25 \mathrm{C}$. Growth on agar slow and sparse, aerobic. On serum grows best at $37 \mathrm{C}$., producing white colonies. It is oval or spherical in form with a deeply staining center. Club-shaped forms present, grampositive. Produces abscess in guinea-pigs after subcutaneous or intraperitoneal inoculation. The organism dies within a week when grown on artificial mediums.

This diphtheroid, according to the few cultural characters given, is in all likelihood identical with C. pyogenes (Glage). The description is too meager to warrant retaining it as a distinct species. The fact that the organism died so readily on artificial mediums indicates that it resembled the hemoglobinophilic type of which Glage's is an example.

\section{B. VARIABILIS LYMPHAE VACCINALIS}

This is the first of several descriptions of a species associated with the vaccine pustules of calves. Nakanishi, in 1900, reported on an organism which he isolated from a vaccine pustule. It is club-shaped, coccoid, segmented or branched. Stains poorly with Gram, facultative anaerobe, nonmotile. Central granule noted when stained with warm fuschin. Growth on serum is abundant. Pale yellow or orange-yellow pigment produced. Poor growth on gelatin. Spore-formation is questionable. The name of this species is not a binomial and therefore may be discarded. A somewhat later and more adequate description by Levy and Fickler is invalid, however, for the same reason. Their organisms were found to be identical with that of Nakanishi and possessed pyogenic properties for guinea-pigs, mice and rabbits. The name given to the species by these authors is Corynebact. lymphae vaccinalis. It is definitely gram-positive. In 1904 this species is met with as Coryneb. pyogenes, so described by Lewandowsky who published a paper almost simultaneously with Galli-Valerio. The last named author found his species to be identical with Nakanishi's and that of Levy and Fickler. Galli-Valerio proposes the name Coryneb. vaccinae (Galli-Valerio). Lewandowsky's designation is a binomial and valid. Galli-Valerio gave no reasons for rejecting a prior description and was apparently unaware of Lewandowsky's work which appeared at the same 
time. The species is best described perhaps as Coryneb. vaccinae (GalliValerio) because the name C. pyogenes had already been used by Glage (q. v.) for an organism isolated from cattle.

B. coryzae segmentosus Cautley; B. diphtheroides citreus; B. diphtheroides brevis; B. maculatus; B. diphtheroides liquefaciens; B. auris; B. ceruminis.

These seven strains were described by Graham Smith. He isolated the first 5 from the nose and mouth, and the last 2 from the ear. B. coryzae segmentosus was first cited by Cautley in a local English government report. The organism is characterized as follows: Nonmotile, gram-positive, polar bodies visible, white growth in gelatin. In broth, clear with sediment. Slight acid produced in dextrose bouillon. Avirulent.

The species' name is objectionable from the etiologic standpoint and violates the rule for binomial nomenclature. This organism has been isolated from normal nasal mucus on numerous occasions and is not necessarily associated with coryza. It differs from C. striatum in its slight acid-producing power in dextrose, its slow growth and small polar bodies. That this species may be obtained from the eye as well as from the nose has been noted by the writer.

In these instances it is to be differentiated from $C$. xerosis by the absence of acidity when grown in maltose and saccharose broths. As a rule C. xerosis ferments these last named sugars (Morse). It is suggested that the name Coryneb. segmentosum nom. nov. be substituted for the invalid B. coryzae segmentosus Cautley. B. diphtheroides citreus corresponds to Coryn. striatum (Chester). It produces yellow pigment. The name given by Graham Smith is not a binomial and disregards priority. It should lapse into synonymy with Coryn. striatum (Chester) Eberson.

\section{B. DIPHTHEROIDES BREVIS}

From pus of oral abscess, Growth on agar, white and slimy. In gelatin, white and dry, clouding in bouillon, granular sediment. Highly acid in sugar broth. This species will be discussed later in connection with diphtheroids isolated from the ear. This organism B. maculatus is meagerly described as an acid-producer. Avirulent. It is impossible to tell wherein this organism agrees with or differs from the main types which have been established in recent studies and for that reason can hardly be looked on as a distinct species until more complete biometrical study is made for strains from a similar source.

\section{B. DIPHTHEROIDES LIQUEFACIENS}

On serum growth is light yellow. Very long bacillus, somewhat curved, with polar bodies. Slightly motile; gram-positive; on agar, growth is thick and moist with light yellow pigment. Gelatin is liquefied in 3 days. In bouillon, slight clouding with granular sediment. In sugar broth reaction is weakly alkaline or neutral. Avirulent. A search through the literature indicates that gelatin liquefying properties have not been associated with diphtheroids, except in this one instance. In 61 strains studied by the writer, but one was found to liquefy gelatin. This species will be described under isolations from ascitic fluids and Graham Smith's organism will be discussed and emended.

\section{B. AURIS}

From aural pus of scarlet fever patient. On serum is similar to that of Klebs-Loeffler organism, but slower in growth. Segmented, nonmotile, grampositive, polar bodies visible. On agar, gray colonies; on gelatin, small trans- 
lucent colonies which become white in three days. Bouillon is clouded slightly and sediment produced. Visible acid produced in sugar broth.

\section{B. CERUMINIS}

From normal ear. Long, thin, curved organism. Gram-positive, polar bodies. Bouillon remains clear with sediment. Neutral or alkaline reaction in sugar broth. Avirulent.

\section{DIPHTHEROIDS FROM THE EAR}

Diphtheroids of the ear have been made the subject of a very valuable paper by Alice Hamilton. In a study of over 50 cases of otitis media and scarlet fever she succeeded in differentiating 2 groups of organisms.

Group 1.--Includes diphtheroids with the following characters: Short rods. gram-positive (weakly staining). Abundant growth on agar. Ferment dextrose and saccharose but not maltose or dextrin. Nonpathogenic.

Group 2.-Long, barred or granular, often clubbed. Gram-positive, scanty growth on agar. Ferment dextrose and maltose, but not saccharose. Often virulent for guinea-pigs.

The pathogenicity of these organisms is altogether different from that of the diphtheria bacterium inasmuch as diphtheria antitoxin did not protect against them. Hamilton's studies showed also that the organisms isolated from otitis undoubtedly have some bearing on the disease since vaccine treatment had a marked effect on opsonic determinations. If we compare this type (Group 2) with the B. auris described by Graham Smith it appears that we have the same organism. Unfortunately the work of the last named author does not mention virulence tests and the strains were too few in number to merit comparison. We are safe, however, in recognizing that the diphtheroids found in the ear are not of the same type and that in cases of otitis media and postscarlatinal infections another species, not necessarily of etiologic significance. seems to predominate. The name Coryn. auris (Graham Smith) is proposed.

\section{B. CERUMINIS}

This organism has been observed also by Dr. Dwyer, of this laboratory. This organism fails to ferment any of the sugars and differs from C. Hofmanni in morphology as well as its behavior in broth which remains clear, with sediment. The name should be Coryn. ceruminis (Graham Smith) comb. nov.

There remains for consideration the diphtheroids of Hamilton's Group 1. These organisms differ from C. hoagii (Morse) only in the absence of a salmonpink pigment. In all likelihood these strains conform to this type. Besides these ear diphtheroids, there seems to be a variety which is characterized by vigorous fermentative properties in a number of sugars. Two such strains have been isolated by the writer. A description follows: Gram-positive, small rods, abundant, white glistening growth on agar, no spores. Form large amounts of acid in dextrose, lactose, saccharose, maltose, mannite; and dextrin, but do not split raffinose. Acidity titrations with $\mathrm{N} / 20 \mathrm{NaCH}$ after 48 hours' incubation were as follows:

\begin{tabular}{|c|c|c|c|c|c|c|}
\hline & Dextrose & Lactose & Saccharose & Maltose & Mannite & Dextrin \\
\hline $\mathrm{n} \quad 1$ & 3.2 & 3.5 & 3.9 & 4.0 & 2.8 & 2.3 \\
\hline in 2 & 5.0 & 3.6 & 4.4 & 4.7 & 2.6 & 2.0 \\
\hline
\end{tabular}

These strains were obtained from cases of otitis media. This species is similar to the diphtheroides brevis described by Graham Smith. It is suggested that a 
binomial be used for the species with the emendation noted above, namely, Coryn. acidum sp. nov.

\section{B. PSEUDODIPHTHERITICUS GAZOGENES}

This is the only gas-forming diphtheroid met with in the literature. Jacobson has described it as follows: Isolated from stools of an infant. Is a vigorous gas former, club-shaped with thickened ends. "One of the cultures resembled streptobacilli. This character did not persist in the transplants." Gram-positive and "in cultures a few days old gram-negative organisms were observed." No spores. Good growth in gelatin, after 5-6 days. Litmus milk is reddened in 24 hours. Nonpathogenic. From the description given by the author it does not seem likely that we have to deal with one organism. Several things point to the impurity of the culture. Isolation from feces, as was here the case, makes such contamination all the more probable. According to the definition of a diphtheroid, this organism which is here described is hardly to be reckoned as one of the genus Corynebacterium.

\section{DIPHTHEROIDS AND ACNE VULGARIS}

Unna, in 1891, repeatedly found in lesions of acne vulgaris an organism which he concluded was the cause of the disease. He did not isolate the organism ${ }^{\circ}$ in pure culture, but gave it the name "Flaschenbacillus" and described it as follows: Unevenly staining rod having clubbed ends and showing ellipsoid forms. In 1894, Hodara, in a bacteriologic study of acne, reported the presence of two types of bacteria in acne lesions. One type is that of Unna and the other Hodara considers as another variety which is similar in appearance but shows varying morphology. For this species he used the name "Flaschen-KugelBacillus" ("Bacillus á Flacons-Ballons").

Neither of these papers goes into any detail concerning the organisms and are of little, if any, value for classification purposes. The first accurate report on these diphtheroids is given by Sabouraud about 3 years later. Sabouraud studied the bacterial flora of the sebaceous plugs which can be squeezed out of the skin. He found an organism which he claimed to be the true cause of the disease according to his definition, and which he described as follows: Punctiform bacillus, almost coccoid, gram-positive, less than 1 mikron in length. Stains readily with anilin dyes. Requires highly acid mediums for growth. Produces intense clouding in broth. Sabouraud named the organism "bacille de séborrhée grasse."

It was not until 1901, when Gilchrist made a thorough study on the bacterial flora of the skin, that an adequate description is found for the bacteria which were mentioned by Unna and his followers. Gilchrist's description points to the identity of his organism with that of his predecessors. It is gram-positive, stains unevenly and very small. It is anaerobic, although many strains were found to grow aerobically after continued cultivation on artificial culture mediums. Surface smears made with the material from pustules failed to show growth whereas stab cultures and heavily inoculated unbroken pustules always showed growth. The organism is named $B$. acnes by the author. We are still in doubt as to the cause of acne and for this reason B. acnes as a species designation may be criticized. Fleming claims to have obtained beneficial results by the use of autogenous vaccines prepared from similar organisms which he isolated from cases of acne. As Sabouraud pointed out these diphtheroids are found in sebaceous plugs and recent observations of numerous workers as well as of our own, show that these bacteria, anaerobic in character, can be isolated 
very readily from "blackheads" without the use of special mediums. It is believed by some that "blackheads" are to be looked on as a stage of acne. In order to adhere to the rules of priority we should designate this diphtheroid as follows; Coryn. acnes (Gilchrist) comb. nov. Cultural studies with this organism were made by Südmerson and Thompson in 1910. They confirmed Sabouraud's findings as to the suitability of highly acid mediums for cultivating $C$. acnes. One part horse serum to 3 parts of $3 \%$ nutrient agar $(4.0)$ is recommended as a culture medium for isolation. Ordinary glucose agar may be used just as well, however. Fermentation studies show that the organism ferments dextrose, saccharose (slight), maltose, mannite and inulin. Raffinose is fermented by 1 strain and not by another. The authors suggest raffinose as a means for differentiating 2 species. Several strains studied by the writer formed no acid in raffinose and in dextrin.

Virulence tests were made on guinea-pigs and mice. Only the latter succumbed to an injection of 4 loopfuls of a 5 day culture. On necropsy the animals showed a greatly enlarged spleen, enlarged and congested mesenteric glands, enlarged, soft and anemic kidney, congested suprarenals and an enlargement and congestion of the axillary and inguinal glands.

\section{B. PSEUDOTUBERCULOSIS OVIS PREISZ (NOCARD)}

This organism was originally isolated by Preisz and Guinard from necrotic areas in the kidney of sheep. Later, Preisz described the organism more fully. It is gram-positive, nonmotile and club-shaped. On serum it produces a heavy moist growth with golden-yellow pigment. Toxin production is attributed to the organism and is fatal for guinea-pigs, rabbits, goats and sheep. In guineapigs, intraperitoneal inoculation gives rise to an orchitis. In larger animals there is produced a pseudotuberculosis which can be differentiated from true tuberculosis by histologic study of the pseudotubercles which do not show the characteristic giant cells. In a recent paper by Hall and Stone this organism was found to produce suppurative processes throughout the lymphatics in guineapigs. The toxin which is elaborated by the bacterium resembles but is not identical with that of diphtheria, yet is partially neutralized by diphtheria antitoxin. The authors found that the organism was hemolytic in blood agar which did not contain an excess of fermentable carbohydrate. Dextrose and maltose were fermented, but glycerol was not attacked, thus differing from C. striatum which ferments glycerin and like the B. pseudotuberculosis ovis Preisz produces a yellow pigment. Three strains of this organism (horse, sheep, calf) which were sent to the Museum of Natural History by the writer were tested for acid production along with the other diphtheroids. The strain from the calf produced more acid in dextrose and dextrin than either of the other two. The detailed results of the tests were as follows:

$\begin{array}{lcccc} & \text { Dextrose } & \text { Lactose } & \text { Saccharose } & \text { Dextrin } \\ \text { (Horse) } & 1.8 & 0.6 & 0.3 & 0.7 \\ \text { (Sheep) } & 0.9 & 0.3 & 0.3 & 1.7\end{array}$

Coryn pseudotuberculosis (Preisz) comb. nov. is perhaps the correct designation.

\section{B. HOAGII}

Morse described this type in 1912 as representing one of the groups which she established as the result of a biometrical study of 295 strains. The characters may be summarized as follows: Medium-sized bacterium showing solid 
barred and wedged forms with abundant but small and imperfect granules. On serum it produces a very heavy, confluent, glistening growth with a characteristic salmon-pink color. Ferments dextrose and saccharose, but not maltose. The organism was described by Hoag, but not named by him. The species should be written Corynebacterium hoagi (Morse) comb. nov.

\section{CORYNEBACTERIUM HODGKINII}

This name is applied to an organism said to be the cause of a glandular disease about which pathologists and bacteriologists are still at odds. In recent years Bunting and Yates, Rosenow, and Billings have been strong adherents to the belief that Hodgkin's disease is caused by a diphtheroid organism which they have cultivated from glandular material obtained from such patients. Organisms similar to those of Bunting and Yates have been isolated from Hodgkin's cases by Rhea and Falconer recently, and according to the earlier work of Fraenkel and Much, and de Negri and Mieremet have been found in similar cases. Fraenkel and Much thought that the organism was related to the tubercle bacillus since it was found by them to be resistant to antiformin. This character has been shown to be insignificant by de Negri and Mieremet who observed the contrary. This test was made on 60 strains of diphtheroids by the writer and in no case was an antiformin-resistant type observed. The first description of this diphtheroid is given by Fraenkel and Much as follows: Granular, antiformin-resistant, gram-positive, nonacid fast. Avirulent for guineapigs. de Negri and Mieremet add several cultural characters: Plump short rod, granular, polar staining. Grows best at $32 \mathrm{C}$. and prefers.aerobic conditions and alkaline reaction of mediums. Abundant growth on Loeffler's serum, with slimy consistency. Bordet medium of blood-glycerin, potato-extract and agar gives abundant growth in 24 hours. According to Bunting and Yates, gelatin is not liquefied and broth is not clouded, but sediment is formed. In this paper it is not proposed to discuss the etiology of Hodgkin's disease, but in reviewing the work of others and from personal studies, it seems that we are not yet ready to ascribe to these diphtheroids the great importance which has been given to them. That organisms similar to these can be isolated from normal individuals as well as from a variety of diseased conditions has been well shown by Bloomfield who made a study of the bacterial flora of lymphatic glands. He found avirulent organisms which were correlated with saprophytes on the body surface in cases of Hodgkin's disease, lymphosarcoma, carcinoma. Another group of organisms seemed to possess a relation to oxygen supply. These were of frequent occurrence. They are short, pleomorphic rods, gram-positive, nonacid fast, no polar bodies and exhibit clubbed forms. Bloomfield found these in cases of lymphosarcoma, arthritis, carcinoma and Hodgkin's disease. Virulence tests on rabbits, guinea-pigs and mice were negative. He concludes that definitely diseased glands yield a greater number of successful cultures than do normal glands. Saprophytic organisms are filtered out by the glands and become a permanent flora of the same. None of the isolated strains appears to be the etiologic factor in specific diseases. Another study by Fox has thrown further light on the question of secondary invasion. Fox found that no one bacterial variety with definite morphologic and cultural characters has been isolated from cases of Hodgkin's disease. That these diphtheroids may be found in enlarged glands in other conditions is mentioned by Fox and has been observed by the writer who has isolated organisms morphologically and culturally identical with the so-called C. Hodgkinii, from an hypertrophied tonsil and from lymph nodes and other sources. For the sake of comfarison the fol- 
lowing table is given so as to show the lack of uniformity in Hodgkin's strains which our study has so far illustrated.

A glance at Table 1 shows that the strains isolated from Hodgkin's cases not only differ among themselves, but are not to be distinguished from organisms obtained from widely varying sources. The study of Hodgkin's disease is to be the subject of another report. Until the etiology of Hodgkin's disease is more definitely ascertained, it is suggested that C. Hodgkinii should not be retained as a valid species inasmuch as the two $\mathrm{C}$. Hodgkinii (Rosenow) strains are widely different in cultural characters. In view of the fact that other organisms which are in no way related to this disease or any adenopathy resembling it, are culturally and morphologically identical with this organism, the name Hodgkinii serves no purpose and leads to confusion.

TABLE 1

Sirowixg the Lack of Uniformity in Acid Production in Hodgkin's Sthains

\begin{tabular}{|c|c|c|c|c|c|c|c|}
\hline \multirow[b]{2}{*}{$\begin{array}{l}\text { Cul- } \\
\text { ture }\end{array}$} & \multirow[b]{2}{*}{ Source } & \multicolumn{6}{|c|}{ N/20 Acld Produced in } \\
\hline & & Dextrose & Lactose & $\begin{array}{l}\text { Saccha- } \\
\text { rose }\end{array}$ & Maltose & Mannite & Dextrin \\
\hline 1 & Hodgkin's (Bunting)....... & 0.2 & 一 & - & 0.3 & - & - \\
\hline 2 & Hodgkin's (Bunting)....... & 0.7 & - & - & 1.1 & 一 & 0.2 \\
\hline 3 & Lymphocytic leukemia.... & 0.3 & - & - & 0.5 & - & - \\
\hline 4 & Acute pseudoleukemia...... & 0.2 & 2.5 & - & 0.5 & - & 0.3 \\
\hline 5 & Hodgkin's (Bunting)....... & 0.2 & - & - & 0.3 & $\rightarrow$ & - \\
\hline 6 & Blood (Bunting)............ & 0.2 & - & - & 0.3 & - & - \\
\hline 3 & C. Hodgkinil (Rosenow).... & 2.8 & - & 1.9 & 2.7 & - & 0.3 \\
\hline 10 & Blood (Eberson)........... & - & - & - & 0.2 & - & - \\
\hline 11 & Tonsil (Eberson) ........... & 0.2 & - & - & 0.4 & - & - \\
\hline 12 & Anal pus pocket (Eberson). & - & 一 & - & 0.3 & - & - \\
\hline 13 & C. Hodgkinfi (Rosenow).... & 0.1 & 一 & - & 0.3 & - & - \\
\hline 15 & Bone marrow (Eberson).... & 0.2 & 一 & $\longrightarrow$ & 0.2 & - & - \\
\hline 28 & Hodgkin's (Rosenow)...... & 0.9 & - & - & 1.7 & 一 & - \\
\hline 34 & Hodgkin's (Rosenow)...... & 2.0 & - & 1.7 & 2.9 & - & 0.3 \\
\hline 38 & Hodgkin's (Rosenow)...... & 1.9 & $\rightarrow$ & - & 2.2 & 一 & 0.3 \\
\hline 44 & Lymph node (Eberson)..... & 一 & 0.1 & - & 0.3 & 一 & - \\
\hline 49 & Hodgkin's (Eberson)....... & 0.1 & - & - & 0.4 & - & - \\
\hline 51 & Hodgkin's (Eberson)....... & 1.5 & - & 1.7 & 1.7 & - & 0.3 \\
\hline
\end{tabular}

\section{DISTRIBUTION OF DIPHTHEROIDS}

At this point it seems convenient to tabulate the diphtheroids which have been found in glands and tissues and arrange the several species which have not been classified heretofore.

\section{Diphtheroids in Glands and Tissues}

The following signs indicate acid production:, \pm 0.1 to $0.5 \mathrm{~N} / 20 \mathrm{NaOH}$ required for neutralization;,+ 0.6 to $1.0 \mathrm{~N} / 20 \mathrm{NaOH}$ required for neutralization;,++ 1.1 to $2.5 \mathrm{~N} / 20 \mathrm{NaOH}$ required for neutralization;,+++ 2.6 to $4.0 \mathrm{~N} / 20 \mathrm{NaOH}$ required for neutralization; - , no acid; alk, weakly alkaline.

Sugar broths were prepared as follows: $1 \%$ by weight of each of the carbohydrates were added to meat infusion broth prepared according to standard methods. The carbohydrates used were Merck's C. P. lactose, saccharose, maltose, mannite and raffinose and Kahlbaum's dextrose and dextrin. Difco peptone was used in preparation of broth. To the mediums (sterilized in Arnold for 20 minutes on 3 successive days and immediately cooled) was 
added sterile ascitic fluid in the proportions of 1 in 10 . The mediums were then incubated at $37 \mathrm{C}$. for 24 hours and 1 day at room temperature to test for sterility. For inoculation, 48-hour cultures of the diphtheroids grown on ascitic dextrose agar ( $0.5 \%$ dextrose) were used. Titrations were made in the cold after 48 hours' incubation, using N/20 NaOH. Five c c of the broth were used for titration. Instead of adding $45 \mathrm{c} c$ of water and a few drops of phenolphthalein to each $5 \mathrm{c}$ c of material, it was found more convenient to add phenolphthalein to a large volume of water and then to make this exactly neutra! by addition of a small amount of $\mathrm{N} / 1 \mathrm{NaOH}$, as was necessary for the water used in the tests. In this way, errors due to variations in reaction of dis tilled water may be avoided. This method and the procedure followed in the preparation of mediums were adhered to in all titrations.

TABLE 2

Tile Acid-Producing Properties of Diphtheroids Found in Glands and Tissues

\begin{tabular}{|c|c|c|c|c|c|c|c|c|}
\hline $\begin{array}{l}\text { Cul- } \\
\text { ture }\end{array}$ & Source & $\begin{array}{l}\text { Dex- } \\
\text { trose }\end{array}$ & $\begin{array}{l}\text { Lac- } \\
\text { tose }\end{array}$ & $\begin{array}{l}\text { Saccha- } \\
\text { rose }\end{array}$ & $\begin{array}{l}\text { Mal- } \\
\text { tose }\end{array}$ & $\begin{array}{l}\text { Man- } \\
\text { nite }\end{array}$ & $\begin{array}{l}\text { Dex- } \\
\text { trin }\end{array}$ & $\begin{array}{l}\text { Raffi. } \\
\text { nose }\end{array}$ \\
\hline B.* 1 & Hodgkin's disease................. & \pm & - & - & \pm & - & - & - \\
\hline B. 2 & Hodgkin's disease................ & $\bar{t}$ & - & - & + & - & \pm & \pm \\
\hline B. 3 & $\begin{array}{l}\text { Axillary gland, lymphocytic leu- } \\
\text { kemia }\end{array}$ & \pm & - & - & \pm & - & - & - \\
\hline B. 4 & $\begin{array}{l}\text { Cutaneous tumor, acute pseudo- } \\
\text { leukemia................................ }\end{array}$ & \pm & ++ & - & + & - & \pm & ++ \\
\hline B. 5 & Hodgkin's disease................. & \pm & - & - & \pm & - & 二 & alk \\
\hline B. 6 & Hodgkin's disease.................. & $\mp$ & - & - & $\mp$ & - & - & - \\
\hline R. 8 & & $+\bar{t}+$ & - & ++ & $+\overline{+}+$ & - & \pm & alk. \\
\hline 10 & 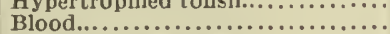 & \pm & - & 二 & \pm & $\overline{-}$ & 二 & $\bar{z}$ \\
\hline II & Hypertrophied tonsil............. & $\mp$ & - & - & \pm & - & - & - \\
\hline R. 13 & 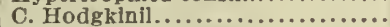 & $\mp$ & - & - & \pm & - & - & - \\
\hline $13 \mathrm{t}$ & Hypertrophied tonsil.............. & 二 & - & - & 二 & - & - & - \\
\hline $14 \mathrm{t}$ & 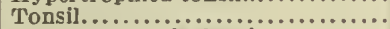 & - & - & - & - & - & - & - \\
\hline 15 & Bone marrow, jeukemia............ & \pm & - & - & \pm & - & - & alk. \\
\hline $27 \mathrm{t}$ & Hypertrophled tonsil............. & 二 & - & - & 三 & - & - & - \\
\hline R. 28 & 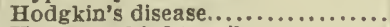 & + & - & - & ++ & - & - & - \\
\hline 29 & Hypertrophied tonsil.............. & - & - & - & - & - & - & - \\
\hline R. 34 & Hodgkln's disease................ & ++ & - & ++ & $++t$ & - & \pm & alk. \\
\hline 35 & Hypertrophied tonsil............... & \pm & - & - & \pm & - & \pm & - \\
\hline R. 38 & 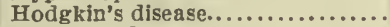 & + & 一 & - & $\overline{++}$ & - & $\mp$ & alk. \\
\hline 44 & Lymph node.................... & - & \pm & - & \pm & - & & - \\
\hline 47 & Brain, meningltis................... & $t+t$ & $+\bar{t}+$ & & + & - & & - \\
\hline 49 & Hodgkin's disease................ & \pm & - & - & \pm & - & - & $=$ \\
\hline 51 & Hodgkin's disease................. & $\overline{t+}$ & & ++ & ++ & & \pm & - \\
\hline
\end{tabular}

* B. = Bunting strains; R. = Rosenow strains.

Diphtheroids isolated from glands and certain tissues fall into several groups: (1) Those which ferment dextrose and maltose slightly; (2) those which ferment dextrose, saccharose, maltose vigorously and dextrin slightly; (3) those which ferment dextrose and maltose vigorously; (4) those which ferment dextrose and maltose vigorously and dextrin slightly; (5) those which ferment lactose, maltose and raffinose vigorously, and dextrin and dextrose slightly; $(6)$ those which ferment lactose and maltose slightly; (7) those which ferment none of the sugars; and ( 8 ) those which ferment dextrose, lactose and maltose vigorously. That the range of fermentative powers varies widely is 
seen at a glance. Before any systematic classification is attempted many more strains must be isolated from lymph glands and tissues. A few new strains will be described here, however.

The diphtheroids which were isolated from tonsils, of which 224 were studied, varied in morphology from very small rods to large club-shaped forms. They were all gram-positive, nonmotile, nonacid fast, nonspore forming, aerobic, and failed to produce gas in carbohydrate mediums. Four were hemoglobinophilic. A few of those strains possessed hemolytic properties. One produced an orange pigment when grown on ascitic dextrose agar slants. This property was observed on ordinary agar as well. Diphtheroids with orange pigment had not been described in the literature at this time, and it is suggested that this organism be called C. aurantiacum. A similar species was obtained from a Hodgkin's gland. The pigment production was studied from the standpoint of oxygen and temperature requirements. At room temperature $(18-25$ C.) under aerobic and anaerobic conditions, pigment was produced abundantly in from 24-48 hours. At 37 C. under aerobic conditions, the orange color was abundant in the same interval of time, whereas under anaerobic conditions, a very slight coloration was observed after 10-14 days. The organism is gram-positive, nonmotile, does not form spores, is not acid fast and is facultative. On ascitic dextrose agar, it grows abundantly with an orange tinge after 24 hours. It is a small bacterium, coccoid in appearance. No polar bodies or granules seen when stained with the Neisser stain: It grows well in dextrose, lactose, saccharose, maltose, mannite, dextrin and raffinose broth and produces acid in dextrose and maltose. At room temperature abundant growth takes place. Gelatin is not liquefied.

Hemolysis of rabbit corpuscles by diphtheroids is not usually attributed to any but the true Klebs-Loeffler bacterium from severe cases (Schwoner). The organisms isolated from the tonsils were in all cases but one, culturally unlike the diphtheria organism and in this one instance proved to be an avirulent diphtheroid, for which the name C. pseudodiphtheriae sp. nov. is proposed. This organism grows on plain agar, is morphologically like the Klebs-Loeffler bacillus. It shows no growth anaerobically after 7 days and is apparently strictly aerobic. Some of the strains from tonsils required blood for growth and died off rapidly unless transferred frequently. These organisms resembled B. influenzae and were hemoglobinophilic.

Three strains were found which fermented dextrose, saccharose, and maltose vigorously and formed slight acid in dextrin. Raffinose remained neutral or faintly alkaline. These diphtheroids were isolated from glands in patients with Hodgkin's disease. In sugar broths, growth was abundant with even clouding. At room temperature, on ascitic agar abundant growth occurs. At $37 \mathrm{C}$. on the same medium growth is abundant with a heavy creamy consistency and brownish tinge. The organisms, small, ovoid or coccoid, stain readily with anilin dyes, are gram-positive, facultative, nonmotile, do not form spores, are not acid-fast. On rabbit blood-agar plates, brown pigment is formed along the streak growths. On Loeffler's serum, abundant white, glistening growtl takes place. One strain, on first isolation, from the gland on blood plates, exhibited a remarkable likeness to B. tuberculosis in character of growth. The colonies were dry and heaped up and friable. This peculiar property did not persist in later transplants. Antiformin treatment showed these diphtheroids to be nonresistant. The name C. glandulae sp. nov. is suggested for this species. 
While this study was under way, a paper by Torrey appeared dealing with bacteria associated with lymph nodes. He tabulated 4 distinct groups, which when analyzed showed 8 different groups according to fermentation reactions. One of the groups included chromogenic types, chiefly orange-red. This species I have named $C$. aurantiacum. An anaerobic diphtheroid occurring in lymph nodes was described by Torrey and named B. lymphophilus. It is slender, pleomorphic, gram-positive, from $0.5 \times 1.2-3.2$ mikrons. It is not acid-fast, occurs singly or in pairs, is nonmotile; stab cultures in $0.5 \%$ agar show rods of irregular morphology and uneven staining. On Loeffler's medium, raised white growth occurs. In dextrose, high acid is produced, even to the amount of $10+$. It is markedly aciduric and acidophilic. Glycerol is also fermented, but lactose, mannite, inulin and dextrin are not attacked. No gas is produced. In my studies, several strains were isolated which exhibited anaerobic preference for a few generations only, but were not like Torrey's strain either with respect to anaerobic requirements or unusual acid-production in any one carbohydrate. Torrey's results are of special interest in showing that there are several types of diphtheroids commonly present in the lymph nodes of Hodgkin's disease, none of which has definite pathogenic properties or can be accepted as the cause of the disease. In this respect he confirms the findings of Bloomfield and myself.

\section{EYE DIPITHEROIDS}

Diphtheroids isolated from the eye were found to vary in cultural behavior. Three strains were obligate aerobes and produced only a very slight amount of acid in dextrose with $0.5 \mathrm{cc} \mathrm{N} / 20$ acid maltose. Seven other strains, facultative, produced slight acid in the same sugars. One strain grew slightly, if at all, on agar and favored Loeffler's serum. All of these grew rather delicately on ascitic agar and serum. At room temperature growth was slow. The organisms were large, clubbed and striated. The type C. xerosis prevailed.

\section{NASAL DIPHTHEROIDS}

Ten strains were isolated from nasal discharges, mostly in persons with cold in the head. Of these, 5 strains were characterized by slight acid formation in dextrose with marked acid in maltose. The remaining 5 were of 2 types, one which produced slight acid, the other abundant acid in dextrose and maltose. On Loeffler's serum, growth was abundant, white and glistening. Stained with anilin dyes, the organisms appeared short and thick with larger striped forms predominating. They are gram-positive, facultative, nonmotile, do not form spores, are not acid fast and grow well in sugar broths. At room temperature moderate to abundant growth takes place. The type C. striatum prevailed.

\section{DIPHTHEROIDS FROM ASCITIC FLUIDS}

Thirty specimens from cases of cirrhosis and tuberculosis were studied anaerobically and aerobically for diphtheroid organisms. No strict anaerobes were found. For anaerobic cultures, Buchner tubes (Zinsser's modification*) were used. Three strains were isolated. All are gram-positive, nonmotile, do not form spores, are not acid-fast, are facultative. Two strains grow very rapidly at room temperature, a third does not. One liquefies gelatin and gives rise to an offensive odor after several days. In broths, the following results were noted (litmus used as indicator).

* A piece of absorbent cotton is pressed down over the pyrogallol to prevent rapid mixing wilh the NaOH. 
$\begin{array}{cccccccc}\text { Strain } & \text { Dextrose } & \text { Lactose } & \text { Saccharose } & \text { Maltose } & \text { Mannite } & \text { Dextrin } & \text { Raffinose } \\ 9 & + & - & + & + & + & + & - \\ 42 & - & - & - & - & - & - & = \\ 43 & - & - & - & - & - & - & -\end{array}$

Strain 43 liquefies gelatin and produces a putrid odor. This strain, practically conforms to the description given by Graham Smith to a liquefying diphtheroid which he named B. diphtheroides liquefaciens. Motility is lacking, however. As was mentioned before, it does not seem as if this property is peculiar to the group with which we are dealing. The organism isolated from ascitic fluid is slender, curved and appears granular. It does not form spores, is facultative, grows abundantly with confluent mass on agar at room temperature and at $37 \mathrm{C}$. and gives off a decidedly putrid odor. On Loeffler's serum it produces a heavy white, moist and glistening layer. It is suggested that the name C. putidum sp. nov. be given to this species. Strain 9 is characterized by its wide range of fermenting power. It is a very small rod, not much larger than B. influenzae. On first isolation, club-shaped forms predominated. It is gram-positive, nonmotile, does not form spores, is facultative, forms acid in dextrose, saccharose, maltose, mannite and dextrin. It grows abundantly at room temperature and at $37 \mathrm{C}$. On Loeffler's serum, abundant growth occurs. It does not liquefy gelatin. C. ascites sp. nov. is proposed as a name for this diphtheroid. Strain 42 is a small gram-positive organism, nonmotile, forms no spores, grows moderately on ascitic agar at $37 \mathrm{C}$. In the early generations this organism showed a decided preference for anaerobic conditions. No growth takes place at room temperature after 10 days. It does not liquefy gelatin and does not ferment sugar broths. Grows best in raffinose broth. This seems to be the most selective medium for obtaining abundant growth. All of the diphtheroids studied grew moderately well and for the most part abundantly in the presence of this trisaccharid when other sugars used for fermentation studies showed little or no growth other than a sediment. C. delicatum sp. nov. is suggested as the name for this species (see blood diphtheroids).

In the early generations this organism showed a decided preference for anaerobic conditions.

A peculiarity noted in the isolations from ascitic fluids was the fact that the first generation always had larger clubbed and knobbed forms. In succeeding subcultures only very small diphthervids were seen.

\section{DIPHTHEROIDS IN BLOOD CULTURES}

Two strains were isolated from blood cultures in cases of pneumonia. In the first generation these showed larger clubbed forms and small rods. Growth is delicate. The organisms are small gram-positive, nonmotile, facultative and produce very slight acid in dextrose or maltose but as a rule leave all sugars unfermented. Gelatin is not liquefied and growth at room temperature is negative after 10 days. On Loeffler's serum moderate growth occurs. These diphtheroids have been identified with C. delicatum.

\section{SKIN DIPHTHEROIDS}

Hine working with 34 strains of diphtheroids found a group which was associated with skin wounds or diseased cavities opening on to or near the surface. Strains of this group were found to acidify dextrose, saccharose usually and less often maltose. The author did not describe these organisms. That diphtheroids can be found on the skin very readily is well established. Juaging by the amazing number of sources from which the organisms of this group may 
be isolated, it scems highly probable that we have to deal with saprophytes which abound everywhere like numerous specics of the Coccaceae group and which gain entrance into the body through the various openings, both normal as well as pathologic.

In the course of this study 4 strains were isolated from an anal pus pocket and from the skin on the neck. Two of these strains which will be described below are in accord with those mentioned by Hine; the other 2 differ sufficiently from these in fermentative and other cultural characters to warrant their acceptance as other species.

(1) Skin Diphtheroid: On Loeffler's serum, abundant dull white growth is produced. On agar delicate growth takes place. Gelatin is not liquefied. At room temperature little growth is observed after 1 week. The organism is gram-positive, nonspore forming, nonmotile, facultatively aerobic, small, ovoid and stains readily. Slight acid is produced in dextrose and maltose, the latter being more strongly acidified. It is avirulent. The name $\mathrm{C}$. epidermidis $\mathrm{sp}$. nov. is suggested for this species.

(2) Anal Pus Pocket: On Loeffler's serum abundant, moist and glistening growth occurs. On agar, heavy glistening growth takes place in broth, uniform clouding. Ferments dextrose and maltose vigorously and usually saccharose. It is gram-positive, facultative, nonmotile, does not liquefy gelatin, does not form spores, and grows abundantly at room temperature. It is avirulent. To this species the name C. suppuratum sp. nov. is given. Similar strains have been observed by Trumpp in empyema and by Hine in a suppurating neck gland. The organism in no way appears to be associated with suppuration except as a secondary invader.

\section{DIPHTHEROIDS FROM BRAIN}

One strain was isolated from the brain in a case of meningitis. The organism is gram-positive, ovoid, or coccoid in appearance, nonmotile, nonspore forming. It grows very rapidly at room temperature and at $37 \mathrm{C}$. on ordinary agar. On Loeffler's serum, growth is white and moist. It is avirulent for guinea-pigs and for rabbits injected intraperitoneally and subdurally. Yigorous acid production takes place in dextrose, lactose and maltose. Growth in broth is abundant. Gelatin is not liquefied. Ortmann has reported a diphtheroid isolated from the brain in a case of meningitis but has given no description of the organism. It is purely a secondary invader. The name C. cerebralis sp. nov. is suggested for the species.

\section{DIPHTHEROIDS FROM THE APPENDIX}

One strain was obtained from this source. There was slight suppuration of the appendix. The organism grows moderately on Loeffler's serum. On agar moderate growth occurs. Few clubbed and barred types were observed in the first generation and in the next few transplants. Neisser's granules are present. The organism is fairly large, nonmotile, gram-positive, does not produce spores and does not liquefy gelatin. At room temperature slight growth occurs. In dextrose, lactose, saccharose, maltose and dextrin slight acid is formed. Heavy flaking with sediment, but no clouding, occurs in the broths mentioned.

Hine has obtained a diphtheroid from an appendix but has not described the organism. It is a saprophyte and a secondary invader. The name C. flocculens sp. nov. is suggested for this species. 
In all, diphtheroids were obtained from 21 different sources and these fell into 12 distinct fermentation groups, as shown in Table 3. The greatest number of organisms comprised the group of nonfermenters and here is to be noted the fact that of 13 strains from Hodgkin's disease, 8 came under this head. However, little significance need be attached to this point, inasmuch as strains from Hodgkin's glands fell into four other groups besides this one. In the same way, it is to be noted that strains from the eye and nose fall into 4 and 3 different groups, respectively.

TABLE 3

Source and Fermentative Reactions of Diphitueroids

\begin{tabular}{|c|c|c|c|c|c|c|c|c|c|c|c|c|c|}
\hline Source & Dextrose & $\begin{array}{l}\text { Dextrose, } \\
\text { Saccha- } \\
\text { rose }\end{array}$ & $\begin{array}{c}\text { Dextrose, } \\
\text { Maltose }\end{array}$ & $\begin{array}{l}\text { Dextrose, } \\
\text { Lactose, } \\
\text { Saccha- } \\
\text { rose, } \\
\text { Maltose }\end{array}$ & $\begin{array}{c}\text { Dextrose, } \\
\text { Saccha- } \\
\text { rose, } \\
\text { Maltose, } \\
\text { Dextrin }\end{array}$ & $\begin{array}{c} \\
\text { Dextrose, } \\
\text { Saccha- } \\
\text { rose. } \\
\text { Maltose, } \\
\text { Mannite, } \\
\text { Dextrin }\end{array}$ & $\begin{array}{c}\text { Dextrose, } \\
\text { Saccha- } \\
\text { rose, } \\
\text { Maltose }\end{array}$ & $\begin{array}{c}\text { Dextrose, } \\
\text { Maltose, } \\
\text { Dextrin }\end{array}$ & $\begin{array}{l}\text { Dextrose, } \\
\text { Lactose, } \\
\text { Maltose }\end{array}$ & $\begin{array}{l}\text { Dextrose, } \\
\text { Maltose, } \\
\text { Lactose, } \\
\text { Dextrin }\end{array}$ & $\begin{array}{c}\text { Dextrose, } \\
\text { Lactose, } \\
\text { Saccha- } \\
\text { rose, } \\
\text { Maltose, } \\
\text { Mannite, } \\
\text { Dextrin }\end{array}$ & $\begin{array}{l}\text { Nonfer- } \\
\text { menters }\end{array}$ & $\begin{array}{l}\text { To- } \\
\text { tail }\end{array}$ \\
\hline Acne (pustule)....... & 1 & .. & .. & .. & .. & .. & .. & 2 & .. & .. & . & & 3 \\
\hline Appendix $\ldots . . . \ldots \ldots \ldots$ & . & .. & .. & .. & .. & .. & .. & .. & .. & .. & .. & $\ddot{i}$ & 1 \\
\hline Ascitic fluid.......... & .. & .. & .. & .. & .. & 1 & .. & .. & .. & .. & .. & 2 & 3 \\
\hline Bile.................. & . & . & . & $\cdots$ & .. & .. & . & .. & .. & .. & .. & $\cdots$ & . \\
\hline Blood................ & $\cdots$ & .. & *. & $\cdots$ & -. & $\cdots$ & *. & .. & $\because$ & .. & .. & 2 & $\div$ \\
\hline Brain................. & $\because$ & 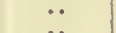 & $\ddot{*}$ & $\ddot{0}$ & $\cdots$ & *. & $\cdots$ & $\cdots$ & 1 & $\cdots$ & $\because$ & $\cdots$ & $\frac{1}{2}$ \\
\hline 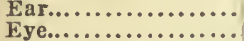 & $\ddot{2}$ & $\ddot{2}$ & $\ddot{i}$ & $\ddot{0}$ & $\ddot{.}$ & $\ddot{*}$ & $\ddot{. .}$ & $\ddot{.}$ & $\because$ & $\because$. & $\begin{array}{l}2 \\
. .\end{array}$ & $\ddot{4}$ & $\frac{2}{9}$ \\
\hline Lymph nodes, Hodg- & & & & $\cdots$ & $\cdots$ & $\cdots$ & & $\because$ & $\cdots$ & $\because$ & $\cdots$ & & \\
\hline Lymph nodes, leuke- & .. & 1 & 1 & .. & 1 & .. & 2 & .. & .. & .. & . & 8 & 13 \\
\hline mia.................. & .. & $\cdots$ & $\cdots$ & $\cdot$ & $\cdots$ & *. & $\cdots$ & *. & *. & *. & $\because$ & $\begin{array}{l}2 \text { (Leu- } \\
\text { kemla 1) }\end{array}$ & 2 \\
\hline doleukemia......... & .. & .. & .. & 1 & $\cdots$ & .. & .. & .. & .. & .. & $\cdots$ & $\because$ & 1 \\
\hline Marrow.............. & $\ddot{q}$ & $\ddot{i}$ & $\cdots$ & $\cdot \cdot$ & *. & $\cdots$ & $\cdots$ & $\cdots$ & $\cdots$ & $\cdots$ & $\because$ & $\frac{1}{5}$ & 1 \\
\hline Nose................. & 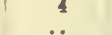 & 1 & $\dddot{i}$ & $\ddot{0}$ & $\because$ & $\because$ & $\ddot{2}$ & $\because$ & $\because$ & $\ddot{*}$ & $\ddot{0}$ & 5 & 10 \\
\hline $\begin{array}{l}\text { Pus (anal pocket).... } \\
\text { Tonsil.................. }\end{array}$ & $\because$ & $\because$ & 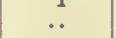 & $\because$ & $\ddot{\cdots}$ & $\ddot{\cdots}$ & .. & $\dddot{i}$ & $\ddot{0}$ & $\ddot{0}$ & $\ddot{. .}$ & $\ddot{2}$ & $\begin{array}{l}3 \\
3\end{array}$ \\
\hline Urine.................. & . & . & .. & .. & .. & . & .. & - .. & . & 1 & . & $\vec{i}$ & 2 \\
\hline $\begin{array}{l}\text { Horse, ealf, sheep } \\
\text { (Preisz Nocard B.) }\end{array}$ & -. & .. & 3 & .. & .. & .. & .. & .. & .. & .. & .. & & 3 \\
\hline Unknown............ & .. & $\cdots$ & 2 & .. & $\cdots$ & $\cdots$ & $\cdots$ & .. & .. & .. & .. & .. & .. \\
\hline Total............ & 7 & 4 & 8 & 1 & 1 & 1 & 4 & 3 & 1 & 1 & 2 & 23 & \\
\hline
\end{tabular}

It becomes evident that neither the source nor the cultural characters serve to distinguish the supposed cause of Hodgkin's disease from numerous organisms which may be regarded as harmless saprophytes: also that diphtheroid organisms comprise a greater number of groups than hitherto supposed.

There appears to be a definite correlation between fermentative properties and source with regard to those organisms which were isolated from the nose and throat. These are characterized by relative inability to ferment carbohydrates. Acid formation in dextrose occurred but 6 times of 19; in dextrose and saccharose. 3 of 19; in 
dextrose and maltose, but 1 in 19 , and of the entire number of strains more than half failed to ferment any sugars. Acid formation, therefore, is limited in its range, never exceeding 2 carbohydrates and showing weak splitting action in general.

\section{CLASSIFICATION}

Classification from the cultural standpoint is difficult because of the manifold variations which are observed. The resolution of all diphtheroids into a few distinct "types" such as suggested by Morse is possible only for a limited number of organisms from a limited number of sources. Lehmann and Neumann classify "pseudodiphtheria" from eye and nose as Coryneb. pseudodiphtheriticum and Coryneb. xerosis, including diphtheroids from both sources under each heading.

More recent work such as that of Plotz on typhus fever (C. typhiexanthematici) indicates that the diphtheroid group may possess pathogenic species which are far removed from the type C. diphtheriae. The organism described by Plotz and his co-workers is an obligate anaerobe with characteristic serum reactions. Some diphtheroids might be classified from the viewpoint of human and animal diseases, and particularly striking cultural characters such as oxygen requirement and sugar fermentations. C. acnes is anaerobic and might very well go into this group of anaerobes. Here also belong those "oxygen tension" diphtheroids which are not anaerobic in the usual sense of the word, but which grow beneath the surface in solid mediums. The property of gelatin liquefaction, not hitherto recognized as a diphtheroid character, suggests another subgroup.

With these points in mind the following classification is offered. An effort has been made to group the species logically but it is evident that relationships between different types do not always permit the most desirable grouping. Certain characters were used as a basis for arranging the distinct species under a chosen type. These will become evident as the tabulation is studied. In the key given here, all of the known diphtheroids have been reviewed and certain new species added.

\section{CLASSIFICATION OF DIPHTHEROIDS}

Group 1.-Diphtheria. Type C. diphtheriae (Klebs-Loeffler).Nonmotile, nonsporeforming, gram-positive, does not liquefy gelatin, shows polar bodies in young cultures. Aerobic and grows between 19 and 42 C. Acid produced in dextrose, maltose and dextrin. Produces 
toxin and gives rise to clinical symptoms known as diphtheria, for which a specific antitoxin exists.

C. pseudodiphtheriae sp. nov. (Fig. 10). - Avirulent organism, morphologically and culturally like $\mathrm{C}$. diphtheriae but produces no toxin and exerts no action when injected into animals. Isolated from hypertrophied tonsils.

Group 2.-Psendodiphtheriticum. Type C. pseudodiphtheriticum (Hofmann-Wellenhoff.)-Nonmotile, nonsporeforming, gram-positive, does not liquefy gelatin. It is shorter and thicker than the C. diphtheriae, but variations such as knobbed, clubbed and barred forms occur. It is avirulent and produces no toxin. In carbohydrates, no acid is produced.

C. ceruminis (Graham Smith) Eberson.-Differs somewhat from C. pseudodiphtheriticum in morphology, as well as in its behavior in broth which remains clear, with sediment. In carbohydrates, no acid is produced. It is avirulent. Isolated from normal ear.

C. delicatum sp. nov. (Fig. 6).-Avirulent strains from ascitic fluids and blood culture. The organism is small and delicate with a decided preference for anaerobic conditions in the early generations. Some strains form traces of acid in dextrose or maltose, but usually ferment none of the sugars.

Group 3.-Xerosis. Type C. xerosis (Neisser and Kuschbert).Nonmotile, nonsporeforming, gram-positive, does not liquefy gelatin. Resembles C. diphtheriae closely morphologically. Acid is produced in dextrose, saccharose and maltose. The organism can be isolated from normal as well as diseased eyes. Growth solid medium is rather delicate.

C. epidermidis sp. nov. (Fig. 7). - Gram-positive, facultatively aerobic, non-sporeforming, does not liquefy gelatin. It is small ovoid in form. Little growth takes place after one week at temperature below $25 \mathrm{C}$. On Loeffler's serum abundant, dull white, growth. Slight acid is produced in dextrose and maltose. It is avirulent. Isolated from skin and pus pockets.

C. suppuratum sp. nov. (Figs. 3, 4).-Gram-positive, nonsporeforming, does not liquefy gelatin. Heavy glistening growth on agar and on Loeffler's serum. Ferments dextrose and maltose vigorously and usually saccharose. Isolated from pus pockets and abscesses. Avirulent. 
C. auris (Graham Snith) Eberson.-Gram-positive, nonsporeforming, does not liquefy gelatin. Long barred or granular, of ten clubbed. Grows scantily on agar. Acid in dextrose and maltose, but not saccharose. It is often virulent for guinea-pigs. Isolated from ear.

C. cerebralis sp. nov. (Fig. 11).-Gram-positive, ovoid or coccoid, nonmotile, nonsporeforming, does not liquefy gelatin. Grows rapidly at room temperature and at 37 C. on agar. On Loeffler's serum, growth is white and moist. Vigorous acid production in dextrose, lactose and maltose. Avirulent for guinea-pigs and rabbits. Isolated from brain.

Group 4.-Nodosum. Type C. nodosum (Migula) Eberson.Large, clubbed forms markedly segmented. Does not form spores, is gram-positive, nonmotile, does not liquefy gelatin, white growth on agar. Acid in dextrose, saccharose, maltose, and dextrin. Found frequently in urine and the urogenital tract. Avirulent.

C. acidum sp. nov. (Figs. 1, 2).-Gram-positive, nonmotile, small rods, with abundant white, glistening growth on agar. No spores, is aerobic and does not liquefy gelatin. Produces large amounts of acid in dextrose, lactose, saccharose, maltose, mannite and dextrin, but does not attack raffinose. Isolated from urine. Avirulent.

C. ascites sp. nov. (Fig. 8).-Gram-positive, small rod with numerous club-shaped forms on first isolation. Nonmotile, nonsporeforming, does not liquefy gelatin, grows abundantly on agar and Loeffler's serum. Forms acid in dextrose, saccharose, maltose, mannite and dextrin. Avirulent. Isolated from ascitic fluid.

C. flocculens sp. nov. (Fig. 13).-Gram-positive, nonmotile, clubbed or barred forms, does not form spores or liquefy gelatin. The organism grows moderately on agar and Loeffler's serum at $37 \mathrm{C}$. At room temperature slight growth. Neisser's granules present. Produces acid in dextrose, lactose, saccharose, maltose and dextrin. Heavy flaking with sediment without clouding in broths. Isolated from a suppurating appendix.

Group 5. - Pigment-forming Diphtheroids. Type C. hoagii (Morse) Eberson.-Medium sized bacterium with solid, barred and wedge-shaped forms with abundant but imperfect granules. On serum a heavy, confluent, glistening growth with a characteristic, salmon-pink color. Gram-positive, forms no spores, does not liquefy gelatin, nonmotile. Produces acid in dextrose and saccharose, but not in maltose.

C. aurantiacum sp. nov. (Fig. 5).-Gram-positive, small and coccoid, nonmotile, nonsporeforming, does not liquefy gelatin, not acid- 
fast. Grows abundantly on agar at room temperature and at $37 \mathrm{C}$. and produces a bright orange pigment. No polar bodies or granules. Grows well in sugar broths and produces acid in dextrose and maltose. Pigment production in 24 hours under aerobic and anaerobic conditions at $18-25 \mathrm{C}$., but at $37 \mathrm{C}$. pigment in this length of time only under aerobic conditions. Under anaerobic conditions, at $37 \mathrm{C}$. a trace of pigment was evident after 10-14 days,

C. glandulae sp. nov. (Fig. 9).--Small ovoid or coccoid bacterium. Grows abundantly at room temperature or at $37 \mathrm{C}$. with a heavy creamy consistency and brownish tinge. Gram-positive, nonmotile, nonspore forming, does not liquefy gelatin. Grows abundantly in sugar broths with uniform clouding. On Loeffler's serum abundant white glistening growth occurs, changing to a brownish color after a few days. Produces acid in dextrose, saccharose and maltose vigorously and slight acid in dextrin. Raffinose neutral. One strain on first isolation from the gland on blood plates showed a remarkable likeness to $\mathrm{B}$. tuberculosis in character of growth; the colonies were dry and heaped up and friable. This peculiarity did not persist in later transplants. Antiformin treatment showed these diphtheroids to be nonresistant. They were not acid-fast. Isolated from glands of Hodgkin's disease.

C. striatum (Chester) Eberson.-Thick form, with clear cut bars. Large and irregular granules visible. Heavy growth on serum with pigment from white to yellow. Ferments dextrose and maltose, but not saccharose. Gram-positive, does not form spores, nonmotile, does not liquefy gelatin. Found in normal nasal mucus.

C. segmentosum nom. nov.-Nonmotile, gram-positive, nonsporeforming, does not liquefy gelatin. Polar bodies demonstrable. In broth, growth is clear with sediment. Slight acid is produced in dextrose. Avirulent, from nasal mucus.

Group 6.-Gelatin-liquefiers. Type C. putidum sp. nov. (Fig. 12). -A slender, curved granular bacterium. It produces no spores, is facultative, grows abundantly with confluent stringy mass on agar at room temperature and at $37 \mathrm{C}$., giving off a decidedly offensive odor. On Loeffler's serum, a heavy, white, moist and glistening mass. It forms no acid in dextrose, lactose, saccharose, maltose, mannite, dextrin and raffinose. Isolated from ascitic fluid.

Group 7.-Anaerobic Diphtheroids Associated with Specific Clinical Manifestations. Type C. typhi-exanthematici (Plotz).-Smaill. pleomorphic, gram-positive organism, not motile, not acid-fast. Most 
of the bacteria are straight, some slightly curved, coccoid forms also occur. The ends are slightly rounded or pointed. Nonspore forming. It is an obligate anaerobe and can be isolated on special glucose mediums containing ascitic fluid of a definite specific gravity. Produces acid in dextrose, galactose, maltose and inulin. Found in typhus fever with regularity; specific serum reactions; pathogenic.

C. acnes (Gilchrist) Eberson.-Gram-positive, small organism, resembling C. typhi-exanthematici. Stains unevenly; anaerobic, but many strains grow aerobically after continued cultivation. Surface smears fail to show growth with material from pustules, whereas deep stab cultures and heavily inoculated unbroken pustules always give growth. Mediums with large amounts of acid especially adapted for isolating this organism which produces acid in dextrose, saccharose (slight), maltose, mannite and inulin. Raffinose is fermented by some strains. Pathogenic for mice and gives rise to characteristic lesions.

Group 8.-Pyogenic Diphtheroids in Animals. Type C. pseudotuberculosis (Preisz) Eberson.-Gram-positive, nonmotile, club-shaped. On serum hcavy moist growth with golden-yellow pigment. Toxin production is attributed to the organism and it is fatal for guinea-pigs, rabbits, goats and sheep. Blood agar with a minimum amount of fermentable carbohydrate shows hemolysis. Acid in dextrose and maltose, but not glycerin. Produces suppurative processes in the lymphatics.

C. pyogenes (Glage).-Gram-positive, nonmotile, club-shaped or cylindrical. Does not grow at room temperature. Is facultatively aerobic, produces no spores and is hemoglobinophilic. Pathogenicity doubtful. No acid produced in dextrose or glycerol.

C. vaccinae (Galli-Valerio).-Gram-positive, nonmotile, clubshaped, coccoid, segmented or branched. Facultatively anaerobic, nonspore forming. On serum, growth abundant; pale yellow or orangeyellow pigment produced; gelatin not liquefied. Pathogenic for guineapigs, mice and rabbits. Associated with vaccine pustules in calves.

Group 9.-Anaerobic Diphtheroids Associaterl with Diseased Lymph Glands. Type C. lymphophilus (Torrey).-Slender, pleomorphic, gram-positive, nonmotile; markedly aciduric and acidophilic; ferments dextrose and glycerol; avirulent. From lymph nodes in Hodgkin's disease.

\section{DISCUSSION}

From this study, which is far from complete, it is evident that the sonrces of diphtheroid organisms have not yet been exhausted. That many strains are yet to be described is a foregone conclusion. The 
bacteriologe study of body fluids and glands and of secondary invaders in common diseases will undoubtedly give us material for ultimate classification. Apart from Morse's biometric study of the diphtheria group, no other classification has been presented. In the light of the material given here it seems as if Morse's classification on the basis of chromogenesis, vigor of growth and fermentative properties is not entirely adapted to the great number of strains which have already been described and which are forthcoming. Serologic studies as a means of classification in this group of bacteria have not been worked out sufficiently to merit much discussion; the little work done has not been of a very searching nature. It seems that here are the most promising possibilities. Agglutination has been tried by Nicholas, Nicolle, Landsteiner, Bruno, Lubowski, Lesieur, and Fraenkel with varying results, which were not specific. The consensus of opinion seems to be that the organisms do not produce agglutinating substances in the serum. Complement fixation has not been sufficiently studied. The results of Morse show that cross-reactions may be obtained for the diphtheroid antigens and that $\mathrm{C}$. diphtheriae does not fix with any of the diphtheroid antigens. The results, however, are not striking enough to be conclusive. The method of preparing antigen undoubtedly will modify the results in such tests. Ground bacteria were used and specific serum obtained by the injection of formalized suspensions of whole organisms. Perhaps Olitzky's method for complement fixation in typhus fever, would be preferable. According to his technic, nonspecific fixation is prevented by the use of Berkefeld filtrates of autolyzed bacteria. It is hoped that by means of group reactions the diphtheroids may be classified definitely. Precipitation tests suggest good possibilities. The reaction is exceedingly delicate and the organisms iend themselves to ready disintegration and extraction.

\section{SEROLOGICAL}

\section{EXPERIMENTS WITH HODGKIN'S STRAINS}

In order to determine the identity of cultures isolated from cases of Hodgkin's disease, two methods were utilized-agglutination and complement fixation. The first method enables us to identify the specificity of the organisms by means of serums obtained from patients suffering with the disease as well as by serums prepared with the different strains of bacteria isolated. Obviously, if the C. Hodgkinii is the cause 
of Hodgkin's disease we ought to be able to show a definite relationship between serums from patients and organisms isolated from these and other cases. By the delicate method of complement fixation we may detect similar antigenic substances and establish the identity, if such there be, of the several strains isolated.

\section{Agglutination}

Four serums, obtained from 4 authentic cases of Hodgin's disease were studied. Eleven strains of bacteria were tested, of which 8 were isolated from glands in Hodgin's disease and the remaining 3 from a case of leukemia, ascitic fluid in cirrhosis and blood.

Forty-eight-hour agar cultures were suspended in salt solution and emulsions made up to approximately the same density. These were shaken with glass beads for thirty minutes and then centrifugated for 5 minutes at low speed to throw down coarser particles. Equal volumes of the different serums (diluted with $\mathrm{NaCl}$ solution) were mixed with the bacterial suspensions in a hanging drop. The preparations were well sealed with vaselin and incubated at room temperature for 1 hour, then at $38 \mathrm{C}$. for another hour, when the results were read.

The results were entirely negative and confirm the results of Fox.

\section{Complement Fixation}

In these experiments the aim was to show by tests for cross fixation what relationship, if any, existed between the different types of bacteria isolated from cases of Hodgkin's disease. The cultures, as in the preceding, were obtained from Drs. Bunting, Yates and Rosenow and from cases studied by me. These strains have been described fully in Part I.

Four strains were used in the production of immune serums from rabbits. These cultures are designated $2,8,13$ and 57 . No. 2 was isolated by Dr. C. H. Bunting from a patient who had a very acute form of Hodgkin's disease; it fermented dextrose and saccharose with acid. No. 8 was sent to me by Dr. E. C. Rosenow, and labeled B. hodgkinii; it produced acid in dextrose, maltose, saccharose, and dextrin.' No. 13 was obtained from the same source; it fermented dextrose and maltose. No. 57 was isolated by me from a case of acute Hodgkin's disease. This organism fermented none of the carbohydrates and was identical in this respect with a strain (No. 1) obtained from Dr. Bunting.

Healthy rabbits, weigling about 1,600 gm., were systematically treated with each of these cultures heated to $58 \mathrm{C}$. for 30 minutes. Injections were made with increasing doses every week for a period of 6 weeks and the serums drawn 10 days after the last injection.

Antigens were prepared by grinding to a fine powder the flocculent precipitate obtained from a mixture of bacteria with an excess of absolute alcohol. The powder was dried in vacuo and then ground in a mortar with solid $\mathrm{NaCl}$. Subsequently sterile distilled water was added to isotonicity and the anticomplementary unit determined.

Complement was obtained from normal guinea-pigs and titrated in the usual way. Sensitizer was prepared with thoroughly washed sheep blood cells injected into rabbits and the unit determined, after which a $5 \%$ suspension of sheep cells was sensitized witl 2 units of the amboceptor. Readings were taken after the tubes were incubated for 15 minutes in a $37 \mathrm{C}$. water bath, and 8 hours in the ice-chest. 
The results showed no correspondence among the separate strains and hence prove them to be nonidentical, a fact which confirms the cultural differences observed in the same organisms. Fox failed to obtain fixation with the serum of a patient and a strain isolated from the glands.

TABLE 1

ReLationship OF TyPE DIPHTHEROIDS

\begin{tabular}{|c|c|c|c|c|c|c|c|}
\hline \multicolumn{8}{|c|}{ Serum Anti-hoagii } \\
\hline \multirow{3}{*}{ Dilution } & \multirow{2}{*}{\multicolumn{3}{|c|}{ Before Absorption }} & \multicolumn{4}{|c|}{ Absorbed with } \\
\hline & & & & \multicolumn{2}{|c|}{ Pseudodiphtherlae } & \multicolumn{2}{|c|}{ Flavldus (Mellon) } \\
\hline & Hoagii & $\begin{array}{l}\text { Pseudo- } \\
\text { diph- } \\
\text { theriae }\end{array}$ & $\begin{array}{c}\text { Flavidus } \\
\text { (Mellon } \\
\text { Strain) }\end{array}$ & Hoagil & $\begin{array}{l}\text { Pseudo- } \\
\text { diph- } \\
\text { therlae }\end{array}$ & Hoagil & $\begin{array}{l}\text { Flavidus } \\
\text { (Mellon) }\end{array}$ \\
\hline $\begin{array}{l}1-20 \\
1-40 \\
1-80 \\
1-160 \\
1-320 \\
1-500 \\
1-1,000 \\
1-1,500 \\
1-2,000\end{array}$ & $\begin{array}{l}++ \\
++ \\
++ \\
++ \\
++ \\
++ \\
+ \\
+ \\
\pm\end{array}$ & $\begin{array}{l}+ \\
+ \\
+ \\
\pm\end{array}$ & $\begin{array}{l}++ \\
++ \\
+ \\
+ \\
+ \\
\pm \\
\pm\end{array}$ & $\begin{array}{l}++ \\
++ \\
++ \\
++ \\
++ \\
++ \\
+ \\
\pm \\
\pm\end{array}$ & $\begin{array}{l}\bar{z} \\
\bar{I}\end{array}$ & $\begin{array}{l}++ \\
++ \\
++ \\
++ \\
++ \\
++ \\
\pm \\
\pm\end{array}$ & $\begin{array}{l}\bar{z} \\
\bar{z}\end{array}$ \\
\hline
\end{tabular}

Serunl Antl-pseudodiphtheriae

\begin{tabular}{|c|c|c|c|c|c|}
\hline \multirow[b]{2}{*}{ Dilution } & \multicolumn{3}{|c|}{ Before Absorption } & \multicolumn{2}{|c|}{ Absorbed with Flavidus (Mellon) } \\
\hline & $\begin{array}{l}\text { Pseudo- } \\
\text { diphtheriae }\end{array}$ & $\begin{array}{l}\text { Flavidus } \\
\text { (Mellon) }\end{array}$ & Hoagii & $\begin{array}{c}\text { Yseudo- } \\
\text { diphtheriae }\end{array}$ & $\begin{array}{l}\text { Flavidus } \\
\text { (Mellon) }\end{array}$ \\
\hline $\begin{array}{l}1-20 \\
1-40 \\
1-80 \\
1-160 \\
1-320 \\
1-500 \\
1-1,000 \\
1-1,200\end{array}$ & $\begin{array}{l}++ \\
++ \\
++ \\
++ \\
++ \\
++ \\
+ \\
+\end{array}$ & $\begin{array}{l}+ \\
+ \\
+ \\
\pm \\
\pm\end{array}$ & $\begin{array}{l} \pm \\
\pm \\
\pm \\
\pm\end{array}$ & $\begin{array}{l}++ \\
++ \\
++ \\
++ \\
+ \\
\pm \\
\pm\end{array}$ & $\underline{z}$ \\
\hline
\end{tabular}

Serum Antiflavidus (Mellon)

\begin{tabular}{|c|c|c|c|c|}
\hline \multirow[b]{2}{*}{ Dilution } & \multicolumn{2}{|c|}{ Before Absorption } & \multicolumn{2}{|c|}{ Absorbed with Flavidus (Morse) } \\
\hline & $\begin{array}{l}\text { Flavidus } \\
\text { (Mellon) }\end{array}$ & $\begin{array}{l}\text { Pseudo- } \\
\text { diphtherlao }\end{array}$ & $\begin{array}{l}\text { Flavidus } \\
\text { (Mellon) }\end{array}$ & $\begin{array}{l}\text { Elavidus } \\
\text { (Morse) }\end{array}$ \\
\hline $\begin{array}{l}1-20 \\
1-40 \\
1-80 \\
1-160 \\
1-320 \\
1-500\end{array}$ & $\begin{array}{l}+ \\
+ \\
+ \\
+ \\
+ \\
+\end{array}$ & $\begin{array}{l} \pm \\
- \\
- \\
-\end{array}$ & $\begin{array}{l}+ \\
+ \\
+ \\
+ \\
+ \\
+\end{array}$ & $\begin{array}{l}- \\
z \\
z \\
-\end{array}$ \\
\hline
\end{tabular}

\section{AGGLUTININ ABSORPTION TO DIFFERENTIATE TYPE DIPHTHEROIDS}

The literature on diphtheroids, to my knowledge, does not contain any reference to agglutinin absorption as a method for showing relationships which might exist among overlapping, closely-related types. In view of the fact that the differences which characterize the accepted 
forms are so slight, bacteriologically speaking, such a method suggested possibilities for more definite classification.

The strains studied were obtained from the Museum of Natural History and were marked as follows: C. hoagii, C. flavidus (Mellon), C. pseudodiphtheriae, C. xerosis, C. enzymicus (Mellon), and C. flavidus (Morse).

Agglutinating serums were prepared in rabbits by giving intravenous injections of fresh agar cultures heated at $56 \mathrm{C}$. for 30 minutes. Increasing doses were given every week until a whole culture was reached. The animals gained weight throughout treatment and were bled 10 days after the last injection. Preliminary titrations were made with each of the serums against homologous and heterologous strains, and double absorption of each serum was made with organisms which evidenced some affinity for the agglutinins present.

The results of the absorption experiments indicate that C. hoagii is more inclusive in its antigenic elements, since it possesses group agglutinins for all the other strains, excepting C. xerosis. C. flavidus (Mel-

TABLE 2

Comparative Results

\begin{tabular}{|c|c|c|}
\hline 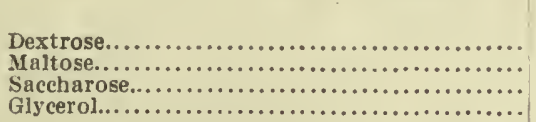 & $\begin{array}{l}\text { Flavidus (Morse) } \\
3.3 \mathrm{c} \mathrm{c} \\
2.0 \\
2.5 \\
3.3\end{array}$ & $\begin{array}{l}\text { Flavidus (Mellon) } \\
2.0 \mathrm{c} \mathrm{c} \\
1.7 \\
1.4 \\
2.6\end{array}$ \\
\hline
\end{tabular}

The figures represent the amount of $\mathrm{N} / 20 \mathrm{NaOH}$ required to neutralize $5 \mathrm{cc}$ of broth culture incubated 1 day at $37 \mathrm{C}$. Growth was heavy In both sets. The Mellon strain gave a flocculate growth and the Morse culture was uniformly clouded.

lon) has no group agglutinins for any of the others and appears to be highly specific. The results vary somewhat as compared with Morse's complement fixation results. Mellon's flavidus shows no group agglutinins at all, although Morse obtained partial cross fixation with her strain. It appeared likely that the former culture sent to the Museum of Natural History as a "B. flavidus," isolated by Mellon, was not a flavidus type. When its homologous serum was absorbed with $\mathrm{C}$. "flavidus" (Morse), the specific agglutinins remained unchanged. That complete absorption by the heterologous strain took place is evident: from the table. Macroscopically, the Morse culture differs markedly on plain agar from the Mellon strain. The latter develops a dull, dry growth, with a tendency to flocculate readily in $\mathrm{NaCl}$ solution, whereas the former is moist and glistening in its growth. In carbohydrates the comparative results were as shown in Table 2.

The relative rate of acid-production by both strains is obviously different. Prolonged cultivation may give somewhat different results. but it has been shown by several workers that the maximum acid- 
production in the usual carbohydrate concentrations is at a maximum after 24 hours. In any case the antigenic properties of both strains are not in agreement, and the cultural tests seem to bear out this difference. Mellon's flavidus may be a subspecies, but it differs from Morse's type too markedly to go by the same species name.

Closer agreement exists in the case of $\mathrm{C}$. hoagii, for which we find on the one hand neither group agglutinins nor cross-fixation for $\mathrm{C}$. hofmanni and C. xerosis, while, on the other hand, there are both cross-fixation and group-agglutination with the flavidus antigen. C. hofmanni shows group agglutinins for C. hoagii and C. flavidus (Mellon), but not for C. xerosis.

TABLE 3

Agglutination Tests and Complement Fixation Study

\begin{tabular}{|c|c|c|c|c|}
\hline \multirow{2}{*}{ Antiserum } & \multicolumn{4}{|c|}{ Antigen } \\
\hline & O. flavidus & C. hoagii, & C. xerosis & C. hofmanni \\
\hline 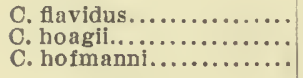 & $\begin{array}{ll}0.025 & (500) \\
0.05 & (500) \\
& (160)\end{array}$ & $\begin{array}{ll}0.1 & (-1-) \\
0.025 & (2000) \\
& (80)\end{array}$ & $\begin{array}{ll}0.1 & (-) \\
\ldots & (-)\end{array}$ & $\begin{array}{ll}0.4 & (20) \\
\cdots & (160) \\
& (1000)\end{array}$ \\
\hline
\end{tabular}

The figures and signs enelosed in parentheses represent the highest dilution in which partial agglutination occurred, and the decimals indicate the amount of antigen in mg. which was necessary for fixation with the different serums. Absorption experiments with a strain of Morse flavidus omitted.

There is no apparent correlation between the reactions in carbohydrates and the antigenic properties. Nonspecific agglutinins appear to be readily absorbed, whereas the specific agglutinins are left intact.

Morse's complement fixation study and the group agglutination tests are shown in Table 3.

\section{PLEOMORPHISM OF DIPHTHEROIDS, MUTABILITY OF TYPES, AND A METHOD FOR DETERMINING MUTANTS}

\section{VARIABILITY OF BACTERIA}

Bacteria are unicellular organisms which are produced from other like organisms by the process of fission-an act in which the entire parent substance may be said to divide itself equally into two fractions, both of which constitute the resulting pair of bacteria. Under such conditions the offspring cannot possess what was not present in the parent. This, in essence, is the pure line concept of bacteria and implies the descendants from any single bacterial cell. The hereditary characteristics of such a biotype do not change as a result of changed 
environnental conditions. In order to explain variations in bacterial types it is necessary to consider both Darwin's theory and that of deVries. The former conception is based on natural selection in which such variations as are better adapted to the struggle for existence will be perpetuated. The theory of deVries holds that the tendency toward variation in the germ plasm may give rise to permanent variations as opposed to fluctuating variations.

When bacteriology was in its infancy it was a popular notion that types could be transmuted readily from one into the other and back again. Strange as it may seem the idea has been reborn and given great impetus within recent years. Pleomorphism is highly developed among the diphtheroids and it is in this group that much confusion has arisen not only as a natural result of the well known overlapping of closely related types, but chiefly because of the ease with which apparently pure cultures of the organisms undergo changes in their morphology. In none of the work presented has the technic been of such a nature as to preclude error. Billings and Rosenow state that single colonies of diphtheroids from Hodgkin's disease "in dextrose agar which showed bacilli only in smears, yielded in subcultures a pure culture of staphylococci aerobically and forms of the bacillus either pure or in mixture anaerobically on the same medium. These facts suggest strongly that the associated staphylococcus is derived from the bacillus." Certainly, no evidence is given by the authors that the single colonies were pure. There is only one method whereby the fallacy may be precluded and that method was not used in this particular instance. It may or may not be true that the staphylococcus was associated with the bacillus, but the word "derived" is misleading. We know from common practice that a single colony even when obtained from highly diluted plate cultures, does not necessarily represent the descendants of a single bacterial cell. Such a mistake was made by Goodman when he claimed to have separated the diphtheria organism into an acid-producing and an alkali-producing type by the plate method, on the assumption that he had a pure line.

I shall deal exclusively with C. enzymicus described and named by Mellon. This organism exhibits the pleomorphism of most diphtheroids but is of especial interest because of the remarkable morphological changes the author claims to have produced. He was able to show a seeming relationship between the diphtheroids and the streptoçocci and described a method whereby he transformed the bacillary type of diphtheroid into a coccus and back again. The old question of sta- 
bility of bacterial type comes up and it is essential that the cardinal points be investigated. Two methods of attack were followed in my studies with C. enzymicus: cultural and serological.

\section{Cultural Study of Mutation}

Two strains of C. enzymicus were studied. One was obtained from the Museum of Natural History and had been cultivated on plain agar for several months. Smears stained with Loeffler's methylene blue showed typical diphtheroid bacillary forms with the usual coccoidal or short rod and extremely small forms (Fig. 14). The second culture was sent by Dr. Mellon. This strain had been cultivated on blood agar for about 1 year and in smear preparations appeared to be practically free from coccoidal forms, showing large uneventy staining bacillary types, varying in size and morphology.

Museum Strain of C. Enzymicus.-A subculture was made on plain agar slants and the 24-hour growth examined. Stains were made from different areas and examined with a $1 / 12$ immersion, using a magnification of approximately 1,400. In all instances diplococci and coccilike organisms were seen grouped like staphylococci and at times singly. Careful examination showed clusters of bacillary forms in small numbers (Fig. 15).

The next step was to obtain a pure culture of the coccus type. Agar plates (meat infusion agar 1.0 to phenolphthalein) were streaked with a platinum loop touched to original culture and several discrete colonies fished. In all cases a single colony was used to prepare a second plate culture and from this generation of single colonies, other plates streaked successively until the 10th generation. Each generation was studied for morphology before seeding. Pure coccus forms were obtained in every case (Fig. 16). No difficulty whatsoever was experienced in procuring a coccus form from the original culture. The real hardship lay in trying to obtain the bacillary type in relatively pure culture, free from cocci.

It is a well known fact that blood and serum mediums exert a favorable influence on the diphtheroid bacteria, causing the development of large clubbed and barred forms. Taking advantage of this fact, and the fortunate "transformation" effected on plain agar, it becomes possible to demonstrate the mechanism of variability in diphtheroids.

Again using the original culture of C. enzymicus I transplanted it to sheep blood agar and examined the culture after 24 hours' incubation. Smears showed cocci and numerous bacillary forms. When subcultured on the same medium the bacillary forms had almost completely outgrown the cocci and a typical diphtheroid picture was seen. As generation after generation on this medium was studied, it was found that cocci disappeared, although not entirely. At times it required careful examination of the microscopic field to discern them among the larger barred and granular forms. A most interesting point was next observed. When subculturing on sheep blood, transfers were made to plain agar slants from the first generation on sheep blood medium. After 24 hours' incubation the agar tubes were found to contain cocci only. As progressive generations on blood medium were transferred to plain agar it became more and more difficult to suppress the bacillary types and to demonstrate the coccus. By the use of various mediums and numerous cross subinoculations it appeared quite clear that the selection of biotypes was dependent on the environment. These details are shown in Chart 1. Certain cardinal points may be observed hy studying the diagram in which evidence is adduced 


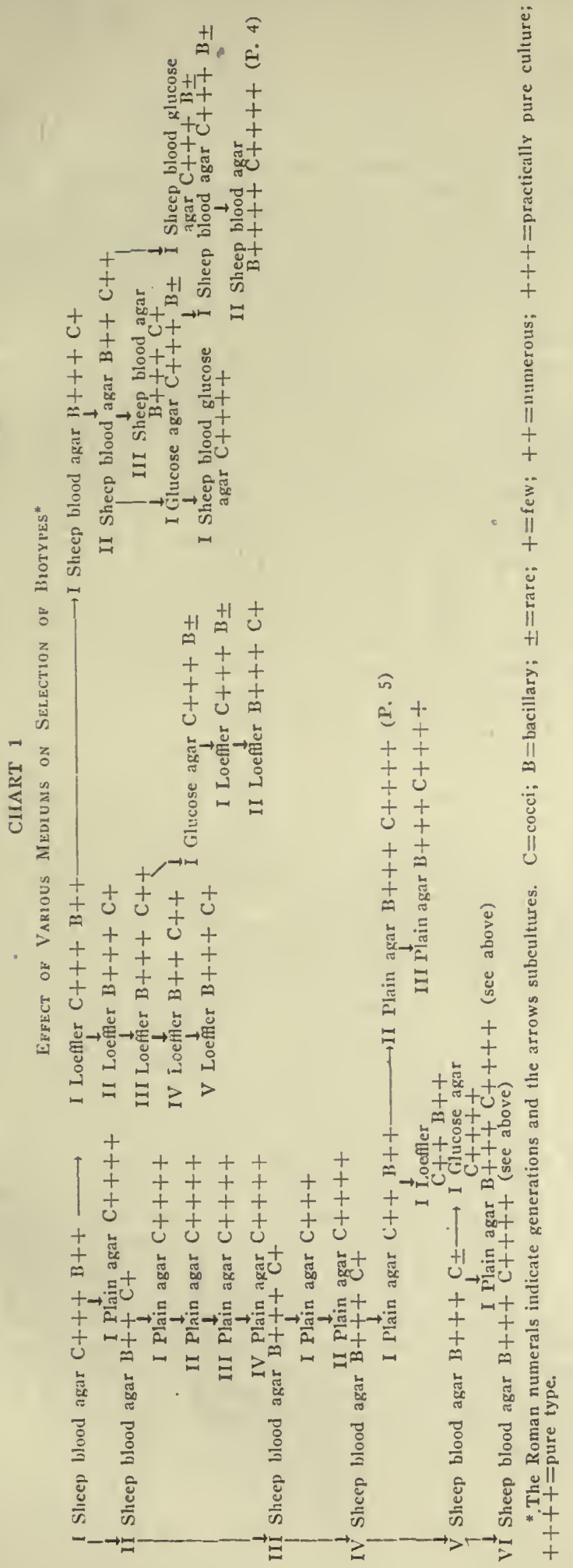


that we are dealing with distinct biotypes side by side in a culture of bacteria. When conditions are optimum for a particular biotype, variations do not occur readily. A new type which may have been brought out in company with the predominating type by a change to a less favorable environment can be suppressed as conditions are restored to normal. It is to be noted, however, that prolonged cultivation under what were at the outset unfavorable conditions, often, if not as a rule, leads to adaptation, and it becomes impossible to obtain a single biotype.

This hypothesis is supported strongly by the following observation: A subculture on plain agar made from the 4th generation on sheep blood medium (bacillary forms predominating) developed a peculiar surface growth of very heavy opaque masses lying in a more or less translucent delicate growth which composed the greater part of the transplant. Microscopic examination of the heavy growth showed purely bacillary forms with isolated cocci, whereas the translucent area gave cocci only. Touching a platinum needle lightly to the heavy mass a second tube of plain agar was inoculated and exactly the same picture was obtained (Figs. 17, 18, and 19, etc.). This was observed on blood medium also (Chart 1). As to the microscopic appearance of the culture it was found that no hard and fast rule can be laid down regarding the character of the bacillary or coccus growth. On any medium the former developed moist and opaque while the latter grew more delicately and transiucent or transparent. These characteristics were observed with the agar strain of C. enzymicus and are diametrically opposed to Mellon's description. The strain cultured on blood medium conformed somewhat to his statement, yet transfers to plain agar gave heavy, moist growth as well as the more delicate and translucent. On fresh Loeffler's medium or blood agar the coccus type could not be distinguished macroscopically from the bacillary form.

To settle the question whether the coccus form is a mutant it is necessary to isolate in pure culture the two biotypes which cultural experiments seem to reveal. A true mutation must appear in a pure line which has been observed over a definite period and shown to consist of a single biotype. As soon as reversion occurs when environmental conditions are restored to normal, we are no longer dealing with a mutation. Different types, to be genuine mutants. must have developed when conditions remained constant. According to Mellon the diplococcus form of $C$. enzymicus when obtained from the barred, long bacillary type, remains quite constant, and although it is possible, as he states. to cause it to assume a bacillary form again, this is accomplished with great difficulty. It is obvious that these characteristics are not those of a true mutant, since the coccus, according to the author, is not obtained until conditions are changed and since it may be transformed to the bacillary type although this is attended with difficulty. Mellon's view is that the organism is extremely pleomorphic and he disregards the likelihood of the coccus being a mutant or a distinct biotype in his original pure culture. It is difficult, admittedly, to prove that the coccus is an entity in the original culture, yet it can be done, especially since there are so many factors in favor of this conception. Mellon goes on to describe the source of his culture and says in part "the rabbit had received intravenous injections of the strain in bacillary form and was recovered from the gallbladder in long chains of streptococci." Is pleomorphism the only possible explanation for this strange transformation? It is just as plausible and simpler to account for this by selective action on the part of the organs for the coccus biotype. 
Experiments with Mellon Strain Cultivated on Blood Medium.-This culture, obtained directly from Dr. Mellon, was morphologically like a typical diphtheroid containing barred, granular, split and clubbed forms, and was relatively free from very minute ovoid bacteria, so far as could be revealed by a routine smear examination. The strain had been cultivated on blood agar for about 1 year and showed well-developed adaptability to this medium.

\section{Study with Pure Lines of C. Enzymicus Bacillary Type}

Sheep blood dextrose agar plates were smeared with a platinum loop lightly inoculated with the original culture. After 24 hours' incubation at 37 C. single colonies were taken for seeding a second series of plates. This process was repeated for 10 generations, using in each instance but 1 colony for the subculture. A single colony, when examined in a smear, always showed the typical bacillary appearance, yet was not "pure" insofar as type was concerned. From 40 to 50 separate colonies selected from each generation were studied microscopically and invariably ovoid and very small coccoid forms could be found in goodly numbers. By carefully examining numerous fields the interesting fact is revealed that a small diplococcus or coccus type is present. Painstaking study of very many microscopic fields is necessary before passing judgment on the presence or absence of these types, but they can be found none the less. Whether or not these diplococci are appearances caused by unusually short ovoid or coccoid forms, I cannot say, since the line of demarkation between these types is not marked, but, as seen, they were distinctly spherical and appeared in pairs. Although the contrast was sufficiently striking with a magnification of about 1,500 diameters, a high power lens with a magnification of 2,500 dispelled any doubt. Where two such organisms were united, one could distinguish the point of union from that which is observed in coccoid and small rod-forms. Witl these observations to go by, Mellon's contention regarding his bacillary culture becomes untenable, and it is perhaps inaccurate to say that "a culture of the C. enzymicus was prepared from a single colony whose antecedents had shown no diplococci." Theoretically as well as practically the culture is absolutely pure but we are not justified, under any circumstances, in assuming that a single biotype can be so obtained. It is not that it is difficult to obtain the bacillary form from the coccus, but that it is difficult, if not impossible, to get the bacillus without the coccus. Agar slants, inoculated with single colonies from various generations plated out according to the technic described, always contained cocci.

"Transition" of Bacillus to Coccus.-The technic of Mellon was repeated carefully in all details, Meat infusion veal glucose broth 1.6 to phenolphthalein was enriched with sterile rabbit serum to the amount of about 5 c.c. per liter. Flasks and tubes were prepared containing 30 c.c. and 10 c.c. of the medium, respectively, and tested for sterility before use. A single colony from the 8th generation of plates made with the bacillary types, previously described, was planted in a tube of this medium, incubated at $37 \mathrm{C}$. for 24 hours and then at $28 \mathrm{C}$. for 3 days. From this tube the sediment was transferred to a flask of the same broth and incubated at $37 \mathrm{C}$. After different intervals smears were made from supernatant fluid and sediment and examined. At no time was any change to a coccus observed, and the picture did not differ in any degree from that seen under ordinary conditions on agar slants. Before we can affirm that the morphologic appearance represents the actual mechanism of transformation, it is essential that a culture of cocci be obtained and propagated for several generations from material showing this "transi- 
tional" picture. Repeating Mellon's technic I have not succeeded in demonstrating this and I find that his paper contains no evidence that such a postulate has been fulfilled. Subcultures were made on agar, after 12, 24, 30, 48,72 , and 96 hours, from individual flasks which had been seeded with the sediment obtained from tubes incubated at 25-28 C. for 3 days. In none of these transplants, incubated at $37 \mathrm{C}$. for 24 hours, was a culture of cocci obtained. There was, however, an abundance of extremely short formscoccoids and some diplococcoids, but nothing to indicate that the bacillary type had undergone any definite change. When cocci are present, the picture is unmistakable and there can be no confusion of this type with the very short forms which look like diplococci (Fig. 26).

It is questionable whether the refined technic of Mellon is needed to demonstrate what is erroneously called a transformation. That all diphtheroid cultures show two distinct forms of organisms is beyond question and that these types may be seen under usual laboratory conditions, is also a matter of common experience. Great caution is necessary in interpreting a morphologic appearance as the actual process responsible for the occurrence of different forms in bacterial culture. Repeated subcultures gave negative results and at no time was it possible to show that complete disintegration had taken place. The "mucus-like débris" and "concentration of chromatin" described by Mellon was seen after 24 hours, not only in broth cultures made according to the special technic described, but also in agar slants grown under conditions to be given. Transfers from broth containing "disintegrated bacillary forms" naturally failed to give mucus-like shreds which are found in smears, but the explanation for this is very simple. Detritus can hardly be expected to grow in transplants. As for the "chromatin masses approaching each other in transplants until the figure cannot be told from a diplococcus," the fact remains that these forms only resemble diplococci. In order to study the effect of lower temperatures on the possible suppression of bacillary forms which might occur during the interval. when the broth cultures are incubated at 25-30 C., a few experiments were performed with agar cultures.

Kinyoun's method for the staining of diphtheria was used. This stain gives most marked granular appearance and is best adapted to differentiating cocci from bacillary bodies with chromatin substance so disposed as to mislead one into taking these for true cocci. Agar slants were prepared from a bacillary culture of C. enzymicus and incubated at $37 \mathrm{C}$. for 24 hours. As usual, some coccus forms could be discerned in smears. The picture, however, was bacillary. Such cultures when incubated further at room temperatures, 21-23 C. for 72 hours, showed in smears numerous diplococci and a marked overgrowth of very short forms. Subcultures maintained at these temperatures always yielded the same results. When transfers were made to agar and incubated at $37 \mathrm{C}$., however, the diplococci became rare and finally could not be found at all. At 28 C. the effect on morphology was evident also. After 48 hours at this temperature, diplococci became numerous, and after 5 days they were present in practically pure culture. Transfers to agar incubated at 28 and $37 \mathrm{C}$. gave, respectively, numerous diplococci and short forms and few diplococci. Broth cultures, kept at $28 \mathrm{C}$. for 1 week, were found to contain numerous diplococci and extremely short forms which could not be distinguished readily from these.

Coccus Type.-A pure culture of cocci was obtained from the original diphtheroid strain, as described previously, and attempts were made to alter its morphology. The results of the experiments showed conclusively that when working with such a pure strain of cocci it is impossible to transform 
it into a bacillus. In the serologic experiments described subsequently it is shown that the coccus is antigenically distinct from the bacillary type and that the extremely short types which are identical in appearance with cocci are merely altered bacillary forms. These "cocci," to be designated here as Strain 28, are antigenically the same as the long, granular rods.

Diphtheroid cocci were grown on Loeffler's serum for 27 generations, and no change was noted in morphology. The organisms remained cocci. On glucose serum medium the forms developed considerably larger and thicker, but were typical diplococci in outline. On agar of various $\mathrm{H}$-ion concentrations ranging from 6.1-5.2, no change in form was observed. The use of potassium bichromate in broth containing various amounts of acid failed to alter the coccus.

A bacillary strain of $\mathrm{C}$. enzymicus was cultivated on plain agar at $28 \mathrm{C}$. for several days and subcultures made from day to day. After one week at this temperature, stained specimens from different slants showed forms which could hardly be distinguished from diplococci. These proved on close examination to be minute rods unevenly stained and bipolars. Such cultures, if transferred to serum medium, assumed the typical bacillary form. Figure 18 illustrates clearly how readily one may err in calling these forms cocci. By comparing them with the true cocci shown in Figure 16 the difference can be seen.

Behavior of Coccus and Bacillary Types in Carbohydrates.-Sugar broths (1.0+ to phenolphthalein) were made in the usual manner, and duplicate sets

TABLE 1

Acid Production

\begin{tabular}{|c|c|c|c|}
\hline & C, Enzymicus-Coccus & $\begin{array}{c}\text { Control } \\
\text { O C }\end{array}$ & O. Enzymicus-Bacllary \\
\hline Dextrose........................ & 7.4 & 1.6 & 7.0 \\
\hline 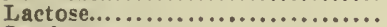 & 6.1 & 1.4 & 7.1 \\
\hline Saccharose.................... & 7.2 & 1.7 & 6.9 \\
\hline 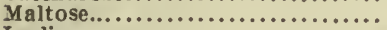 & 8.0 & 1.3 & 7.8 \\
\hline Inulin........................ & 2.1 & 1.8 & 2.0 \\
\hline 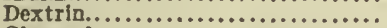 & 3.8 & 1.4 & 4.4 \\
\hline 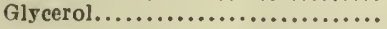 & 2.4 & 1.3 & 7.4 \\
\hline
\end{tabular}

of tubes were inoculated from a 24-hour old agar culture of C. enzymicus (coccus) and C. enzymicus (bacillary). After 8 days' incubation at $37 \mathrm{C}$. the titrable acid formed in each of the carbolydrates was determined by addition of $\mathrm{N} / 20 \mathrm{NaOH}$, using phenolphthalein as an indicator. Titrations were done in the cold. Five c.c. of broth were used in a total volume of 50 c.c. with distilled $\mathrm{H}_{2} \mathrm{O}$.

Examination of the tubes after inoculation with both strains showed the marked difference in rate of growth of the organisms. After 8 hours the coccus type had clouded all of the sugar broths heavily. The bacillary type developed more slowly, and the intensity of clouding after 24 hours approximated that produced by the coccus in a third of the time. Both series showed fine granulation and sedimentation, but this was more pronounced in the case of the coccus.

The acid-production is given in Table 1 . The figures represent the amount of $\mathrm{N} / 20 \mathrm{NaOH}$ required to neutralize acid.

The tabulation shows at a glance that, with the exception of glycerol and dextrin, perhaps, both types behaved similarly in the carbohydrates used. This might be an argument for similarity or relationship of both organisms. The difference observed in glycerol, however, was too marked to escape notice and 
on the basis of this alone would indicate a distinct property not common to both organisms. In order to control the fermentation test, stained preparations were made from both sets of tubes just before titrating, and the apparent similarity of reaction was explained by the selective action of certain mediums on the type of organism. Glycerol was found to inhibit the development of cocci completely; dextrin had a similar action to a lesser degree. In all of the remaining carbohydrates, the bacillary forms liad been suppressed to a remarkable extent.

\section{Serologic Experiments}

Absorption of Agglutinins.-The object of these experiments was to establish, if possible, by means of highly agglutinating serums, the relationship of the bacillary diphtheroid to the diplococcus. Mellon, in his paper, concludes that the streptococci are related to the diplitheroids and can be derived from these. To establish such a claim it would be necessary to obtain pure strains of each of these two types and show that they are mutually interchangeable. This has not been shown by Mellon, and in the work reported here the results

TABLE 2

Absorption Experiments witil Coccus Serum

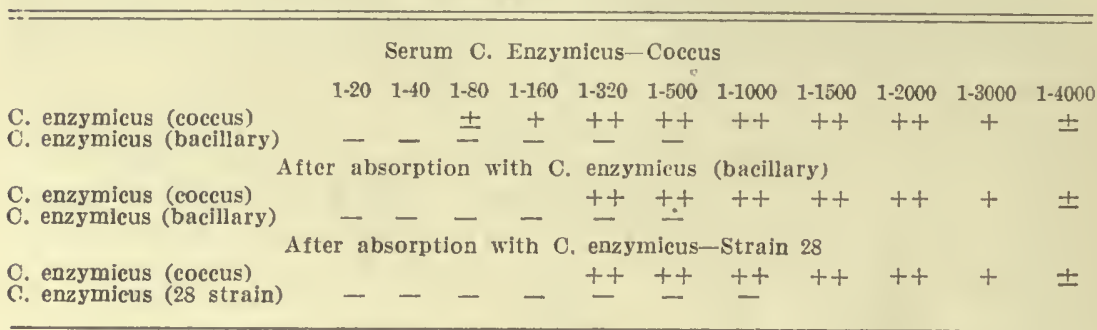

do not substantiate his claim. It is evident that two organisms, derived one from the other, should have similar, if not identical, antigenic properties. To test the validity of such an assumption the most delicate method available is that of agglutinin absorption, when the organisms in question are capable of producing agglutinating serums. If the coccus type, obtained from a diphtheroid culture, is truly derived from the bacillus, then a serum prepared with one strain should agglutinate the other, and the absorption of agglutinins should be demonstrable. With this idea in view, two serums were prepared with the coccus strain and the bacillary strain, respectively.

Healthy male rabbits were injected intravenously at 4-6 day intervals with increasing doses of culture heated to $56 \mathrm{C}$. for 20 minutes. The dosage progressed from $1 / 20$ of an agar slant to a whole culture. Ten days after the last injection the animals were exsanguinated and the serum, after heating to $53 \mathrm{C}$. for 15 minutes, was stored at $4 \mathrm{C}$. until ready for use. The tests were made with serum less than 6 days old.

The technic of absorption was as follows: 24-hour old agar cultures of the organisms were emulsified in a small volume of $\mathrm{NaCl}$ solution, heated to $56 \mathrm{C}$. for 20 minutes, and centrifugated at high speed for a short time. To the sediment so obtained the heterologous serum was added after determining by a preliminary agglutination test the potency of the homologous serum. In order to ensure complete absorption the serums were diluted. The 
mixture of bacteria and serum was incubated at $37 \mathrm{C}$. for $1 \frac{1}{2}$ hours, kept at $4 \mathrm{C}$. over night, and then centrifugated for 20 minutes at high speed. The supernatant serum, pipetted off, was added to another heavy sediment of organisms, obtained as in the preceding, and the absorption repeated, after which agglutination tests were made. A series of dilutions were prepared with each original serum and tubes set up at the same time as the absorbed serum.

The results of these absorption experiments are decisive. A serum prepared with the coccus possesses no agglutinins for the bacillary diphtheroid and when absorbed completely with this bacillary strain evidences no reduction in its agglutination titer against the homologous coccus. The coccus serum when absorbed with a bacillary strain altered morphologically by cultivation at $28 \mathrm{C}$. for 10 days so that the organism

TABLE 3

Absorption Experiments with Bacillary Serum

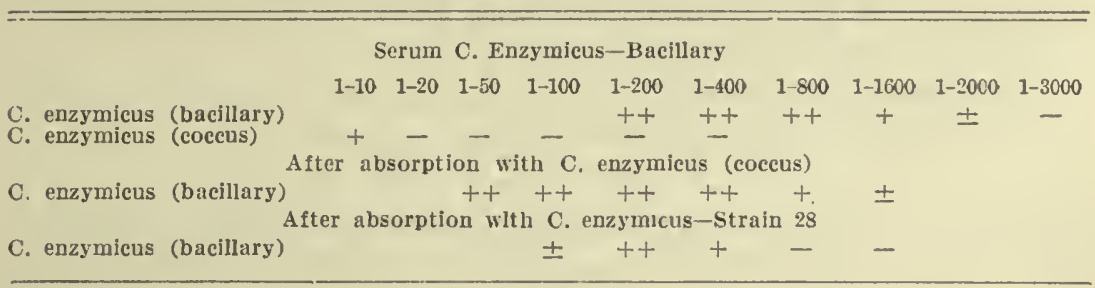

could not be distinguished from cocci, lost none of its agglutinating power for the coccus. Again evidence is adduced that the change on the part of the bacillus was merely an appearance, and that the organisms were not true cocci, but extremely short bacilli, altered perhaps by changes in surface tension to assume a form remarkably like cocci. Antigenically these organisms are therefore distinct from the coccus type. In Table 3 they are shown to be identical with the original bacillary form. The conclusion to be drawn from this experiment is that the coccus has no antigenic elements in common with the bacillus.

The next experiment, made with a serum produced with the bacillary strain of $\mathrm{C}$. enzymicus, gave additional evidence in another direction and confirmed the difference of the two organisms. The serum, although agglutinating its homologous culture as high as 1-2000, gave agglutination in 1-10 for the coccus. This in itself would be an argument against antigenic relationship. The fact that a bacillary strain is never free from cocci, however, would readily explain slight agglutination which might occur. This interesting point is shown quite clearly 
in the absorption test. The serum, after complete absorption with the coccus, showed a reduction in agglutinating titer, stopping at 1-1600, whereas the nonabsorbed serum was positive at $1-2000$. This removal of agglutinins might suggest antigenic similarity on the part of the coccus for the bacillus. The important point to be noted here, however, is the cumulative action of multiple doses of bacillary diphtheroids containing cocci in mixture. Repeated injections of mass cultures have resulted in the formation of agglutinins specific for each type of organism, and the slight reduction in titer is thereby accounted for. As a further corollary, Strain 28 absorbs most of the agglutinins out of the bacillary serum, showing that the organisms are antigenically the same. That the absorption is not more complete may be due to the fact that but one exposure was made with the organism in question, whereas in the case of the coccus strain the serum was doubly absorbed. From these findings the conclusion may be drawn that the bacillus is antigenically distinct from the coccus.

Two possibilties are suggested in explanation of the presence side by side of two biotypes; one is that of mutation and the second a symbiotic relationship of a contaminating coccus and a typical bacillary diphtheroid. The possibility of mutation is not far-fetched, although highly improbable in this instance. As to a symbiosis, the likelihood is less remote. In either case the question can be answered categorically by applying the single bacterial-cell method to the conditions which prevailed in the experiments given here. These experiments will be described in a future paper.

\section{SUMMARY AND CONCLUSIONS}

The diphtheroids have been studied with regard to nomenclature and revised according to accepted standards for the naming of valid species.

A tentative classification is offered with a view toward grouping prominent biologic characters. Nine distinct groups of diphtheroids are outlined with a type species for each group and corresponding subspecies.

It is evident that the groups hitherto accepted as types for all diphtheroids are insufficient and not representative of a broad classification.

Diphtheroids isolated from glands and tissues-21 different sources -fall into 12 distinct fermentative groups. The greatest number of organisms are nonfermenters. Strains isolated from the eye and nose 
do not attack carbohydrates vigorously, and are usually found either in the nonfermenting or in the dextrose-splitting group.

The diphtheroids associated with Hodgkin's disease have been studied. It has been shown that neither the source nor the cultural characters serve to distinguish the supposed cause of Hodgkin's disease from numerous saprophytic diphtheroids. By means of complement fixation tests the conclusion is reached that the cause of this disease is not the organism described by numerous workers.

Agglutinin absorption studies indicate more clearly the relationship which exists between certain members of the diphtheroid group of bacteria. The results are correlated in the main with complement fixation.

Diphtheroids conform to the fundamental laws of bacteriology and are not readily transformed into cocci and back again. Two distinct biotypes have been isolated from a culture of C. enzymicus.

The coccus associated with a bacillary diphtheroid (C. enzymicus) is antigenically distinct from the bacillus and vice versa. Under certain conditions a bacillary strain may be made to assume a diplococcus picture, but absorption experiments show that the organisms are not cocci.

Certain mediums and cultural technic have been found to exert a definite selection on diphtheroid cultures. One or the other biotype will prevail, depending on the extent of suppression of the first or second.

Two explanations for the existence of coccus and bacillus are suggested, either that of mutation or a symbiotic relationship of a contaminating coccus. The question can be settled by applying the single-cell method to the study.

\section{BIBLIOGRAPHY}

Abbot: Bull. Johns Hopkins Hosp., 1891, 2, p. 143.

Baumgarten's Jahrenșbericht, 1891, p. 317.

v. Besser cited by Migula.

Biggs, Park and Beebe: Centralbl. f. Bakteriol., 1895, 17, p. 765.

Billings and Rosenow: Jour. Am. Med. Assn., 1913, 61, p. 2122.

Bloomfield : Arch. Int. Med., 1915, 16, p. 197.

Bruno: Berl. klin. Wchnschr., 1898, 35, p. 1127.

Buchanan: Jour. Infect. Dis., 1915, 17, p. 528.

Bunting and Yates: Arch. Int. Med., 1913, 12, p. 236.

Bunting and Yates: Jour. Am. Med. Assn., 1914, 62, p. 516.

Cautley: Rep. Med. Officer of Health, Local Govt. Board, 1894-5, p. 455.

Chester: Manual of Det. Bact., 1901, p. 171.

Demme: Fortschritte d. Medizin, 1888, 1, p. 7.

Eisenberg: Bakt. Diagnostik, 1891.

Enderlen: Ztschr. f. Tiermedezin, 1891, p. 321. 
Ernst: Ztschr. f. Hyg. u. Infektionskr., 1889, 5, p. 428.

Erisst: Centralbl. f. Bakteriol., I. O., 1906, 40, p. 79.

Fleming: Lancet, 1909, 1, p. 1035.

Flïgge: Ztschr. f. Hyg. u. Infektionskr., 1894, 17, p. 290.

Flïgge: Die Mikroorganismen, 1896, 2, p. 477.

Fox: Jour. Med. Research, 1915, 32, p. 309.

Fox: Arch. Int. Med., 1915, 16, p. 465.

Fraenkel: Berl. klin. Wchnschr., 1897, 34, p. 1087.

Fraenkel and Much: Ztschr. f. Hyg. u. Infektionskr., 1910, 67, p. 159.

Galli-Valerio: Centralbl. f. Bakteriol., I. O., 1904, 36, p. 465.

Gerber and Podack: Deutsch. Arch. f. klin. Med., 1895, 54, p. 262.

Gilchrist: Johns Hopkins Hosp. Reports, 1901, 9, p. 409.

Glage: Ztschr. f. Fleisch, u. Milch hygiene, 1903, 13, p. 166.

Goodman: Jour. Infect. Dis., 1908, 5, p. 421.

Graham-Smith: Centralbl. f. Bakteriol., Ref. 1905, 36, p. 358.

Grips: Ztschr. f. Fleisch u. Milch hygiene, 1898, 8, p. 166.

Gromakowsky: Centralbl. f. Bakteriol., 1900, 28, p. 142.

Hall and Stone: Jour. Infect. Dis., 1916, 18, p. 195.

Hamilton: Jour. Infect. Dis., 1907, 4, p. 326.

Hine: Jour. Path. and Bacteriol., 1914, 18, p. 75.

v. Hofmann: Wien. klin. Wchnschr., 1888, 1, p. 65.

Hodara: Monatschr. f. prakt. Dermat., 1894, 18, p. 573.

Jacobson: Annals de 1'lnst. Pasteur, 1908, 22, p. 308.

Jacobson: Centralbl. f. Bakteriol., Ref., 1909, 43, p. 213.

Klein: Centralbl. f. Bakteriol., 1900, 28, p. 418.

Kolmer: Jour. Infect. Dis., 1912, 12, p. 56.

Kruse and Pasquale: Ztschr. f. Hyg. u. Infektionskr., 1891, 16, p. 1.

Kunneman: Arch. f. wiss. u. prakt. Tierheilk., 1903, 29, p. 128.

Kurth: Ztschr. f. Hyg. u. Infektionskr., 1898, 28, p. 409.

Landsteiner: Wien. klin. Wchnschr., 1897, 10, p. 439.

Lehman and Neumann: Atlas, 1912, 2, p. 570.

Lesieur: Les Bacilles dit. Pseudo-diphteriques, 1902.

Levy and Fickler: Centralbl. f. Bakteriol., 1901, 30, p. 470.

Lewandowsky: Centralbl. f. Bakteriol., I. O., 1904, 36, p. 473.

Loeffler: Centralbl. f. Bakteriol., 1887, 11, p. 105.

Lubowski: Ztschr. f. Hyg. 11. Infektionskr., 1900, 35, p. 87.

Lustgarten: Vierteljahrsschrift f. Derm. u. Syphilis, 1887, p. 914.

Mellon: Jour. Bacteriol., 1917, 2, p. 81.

Migula: System der Bakterien, 2, 1900.

Morse: Jour. Infect. Dis., 1912, 11, p. 251.

Nakanishi: Centralbl. f. Bakteriol., 1900, 27, p. 641.

de Negri and Mieremet: Centralbl. f. Bakteriol., I. O., 1913, 68, ' 292.

Neisser: Ztschr. f. Hyg. u. Infektionskr., 1888, 4, p. 165.

Neisser and Kuschbert: Bresl. ärtztl. Ztschr., 1883, 4.

Nicholas: C. R. de la Soc. de Biol.. 1896.

Nicolle: Annals de 1'Inst. Pasteur, 1898, 12, p. 186.

Olitzki : Jour. Infect. Dis., 1915, 17, p. 1.

Ortmann: Berl. klin. Wchnschr., 1889, 16.

Plotz: Jour. Infect. Dis., 1915, 17, p. 20.

Preisz and Guinard: Kolle Wassermann Handb. d. path. Mikroorganism, 1913. 5, p. 784.

Prochaska: Ztschr. f. Hyg. u. Infektionskr., 1897, 24, p. 373.

Rhea and Falconer: Arch. Int. Med., 1915, 15, p. 438. 
Sabouraud: Annals de l'Inst. Pasteur, 1897, 11, p. 134.

Schwoner: Wien. klin. Wchnschr., 1902, 15, p. 1275.

de Simoni: Centralbl. f. Bakteriol., 1898, 24, p. 294.

de Simoni: Centralbl. 'f. Bakteriol., 1899, 26, p. 673, 757.

Sternberg: Manual of Bacteriology, 1892.

Südmerson and Thompson: Jour. Path. and Bacteriol., 1910, 14, p. 224.

Torrey: Jour. Med. Research, 1916, 34, p. 65.

Trumpp: Centralbl. f. Bakteriol., 1896, 20, p. 721.

Unna: Monatschr. f. prakt. Dermat., 1891, 15.

Weichselbaum: Beiträge zur. patholog. Anatomie und zur allgem. Pathologie, 4, p. 119.

Zinsser and Hiss: Textbook of Bacteriology, 1915. 


\section{EXPLANATION OF PLATES $1-3$}

Fig. 1.-C. acidum. Large forms developing in mediums enriched with serum. $\times 1000$.

Fig. 2.-Same after prolonged cultivation on ordinary mediums. $\times 1000$.

Fig. 3.-C. suppuratum. On serum medium after 1st isolation. $\times 1000$.

Fig. 4.-Same after prolonged cultivation on ordinary medium. $\times 1000$.

Fig. 5.-C. aurantiacum. $\times 1000$

Fig. 6. C. delicatum. $\times 1000$.

Fig. 7.-C. epidermidis. $\times 1000$.

Fig. 8. - C. ascites. $\times 1000$.

Fig. 9.-C. glandulae. $\times 1000$.

Fig. 10.-C. pseudodiphtheriae. $\times 1000$.

Fig. 11. - C. cerebralis. $\times 1000$.

Fig. 12.-C. putidum. $\times 1000$.

Fig. 13. C. flocculens. $\times 1000$.

Fig. 14.- I. Plain agar slant inoculated with material taken from a culture of C. enzymicus grown on sheep blood glucose agar for 4 generations. The sheep blood agar showed numerous rod forms with cocci intermingled. $A,{ }^{1}$ heavy white growth superimposed on a delicate transparent background.

II. Plain agar slant inoculated with material taken from opaque, heavy white growth indicated by $A^{1} . A$, transparent surface growth. $B$, heavy white opaque growth. Smears from $A^{1}$ and $B$ always showed bacillary forms, typical diphtheroids. $A$ yielded pure cocci

Fig. 15.-Smear from heavy growth indicated by $A^{1}$ and $B$ in Figure 14.

Fig. 16.-Smear from transparent delicate growth marked $A$ in Figure 14. Stained with Loeffer's methylene blue. $\times 1000$.

Fig. 17.-C. enzymicus. Original culture.

Fig.18. - Bacillary type developing on Loeffler's serum. Transferred from sheep blood agar on which the original culture had been inoculated. When the original strain (Fig. 17) was planted on plain agar, bacilli could not be demonstrated.

Fig. 19.-Suppression of bacillary type on glucose agar. After 3 generations on Loeffler's serum preceded by 2 generations on sheep blood agar, cocci were rare. Note the predominating type here.

Fig. 20.-Transplant from 3rd generation on sheep blood medium to plain agar. The sheep blood culture showed rare cocci and practically a pure culture of bacillary forms.

Fig. 21.-Same culture before transplanting to plain agar. $\times 1000$.

Fig. 22.-C. enzymicus cultivated on blood agar, then transferred to plain agar and incubated at $28 \mathrm{C}$. "Concentration of chromatin" clearly shown.

Fig. 23.-Transplant from 48-hour veal glucose broth culture of C. enzymicus. Note absence of "transformed" bacilli. The technic according to Mellon.

Fig. 24.-C. enzymicus grown at $28 \mathrm{C}$. in broth. Curious chromatin staining.

Fig. 25.-C. enzymicus 3 rd generation on agar from blood medium. This picture, as well as Figure 22 , is identical with the "transitional" phase.

Fig. 26.-C. enzymicus grown at $28 \mathrm{C}$. on plain agar for 10 days. Note the diplococcus appearance.

Fig. 27.-Previous incubation at $28 \mathrm{C}$. in broth and subsequent growth at $37 \mathrm{C}$. Stained according to Kinyoun's method. $\times 1000$. 
3

Whan

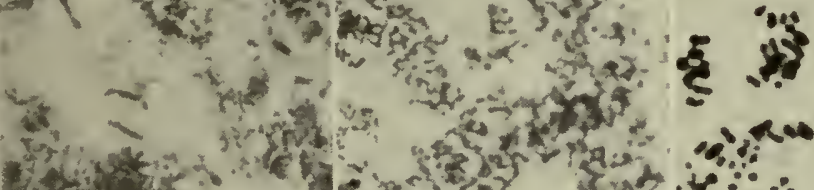

सhint

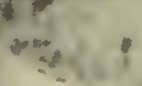

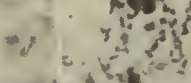

it

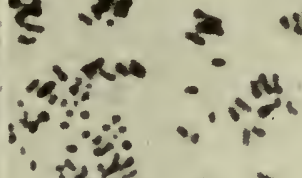

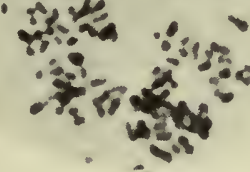

3

हhis?

$x$

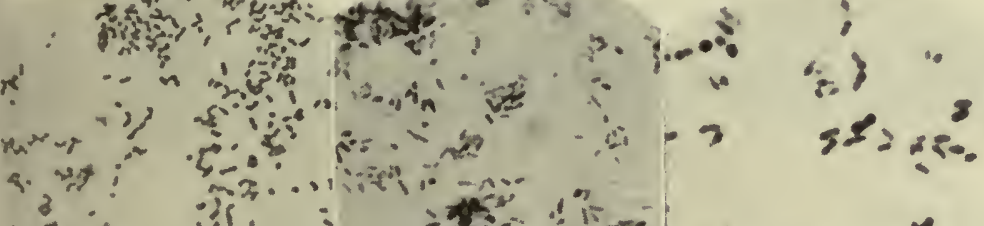

$\therefore$ is i

等 



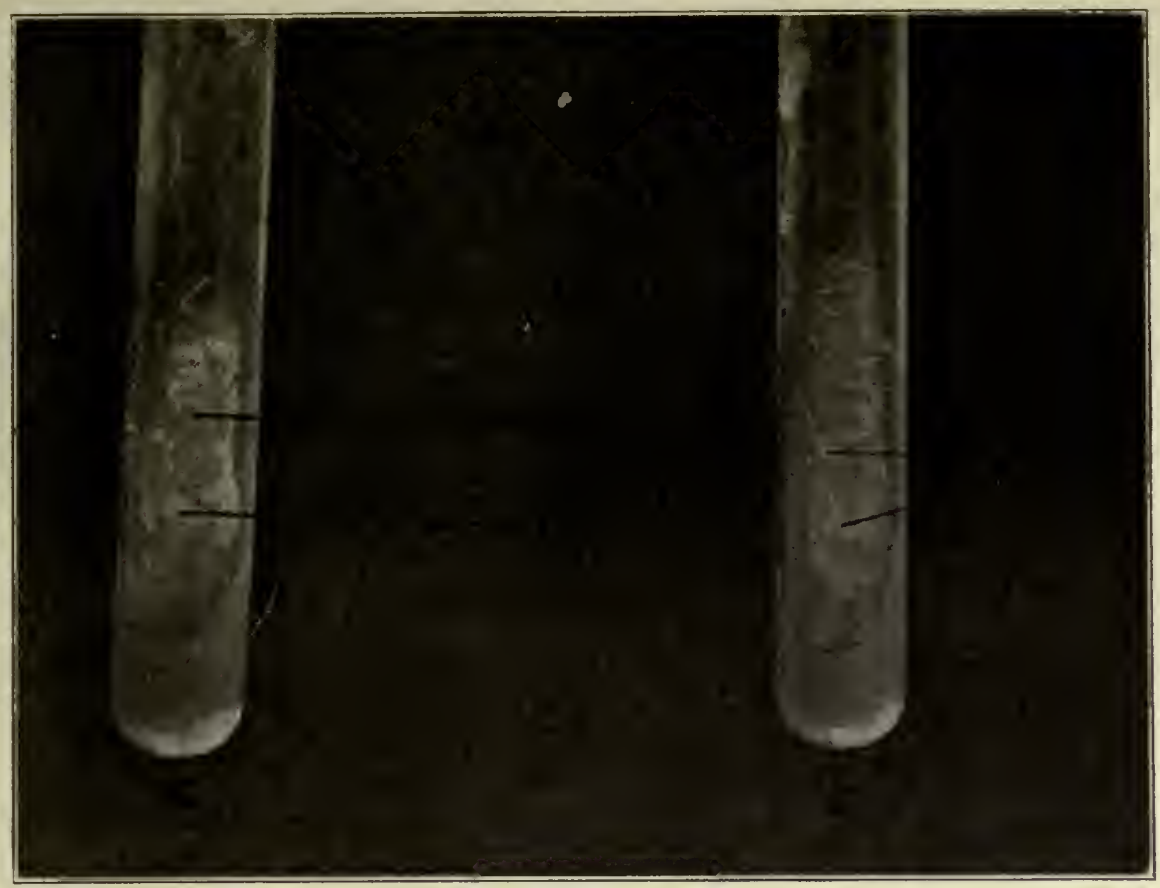

14
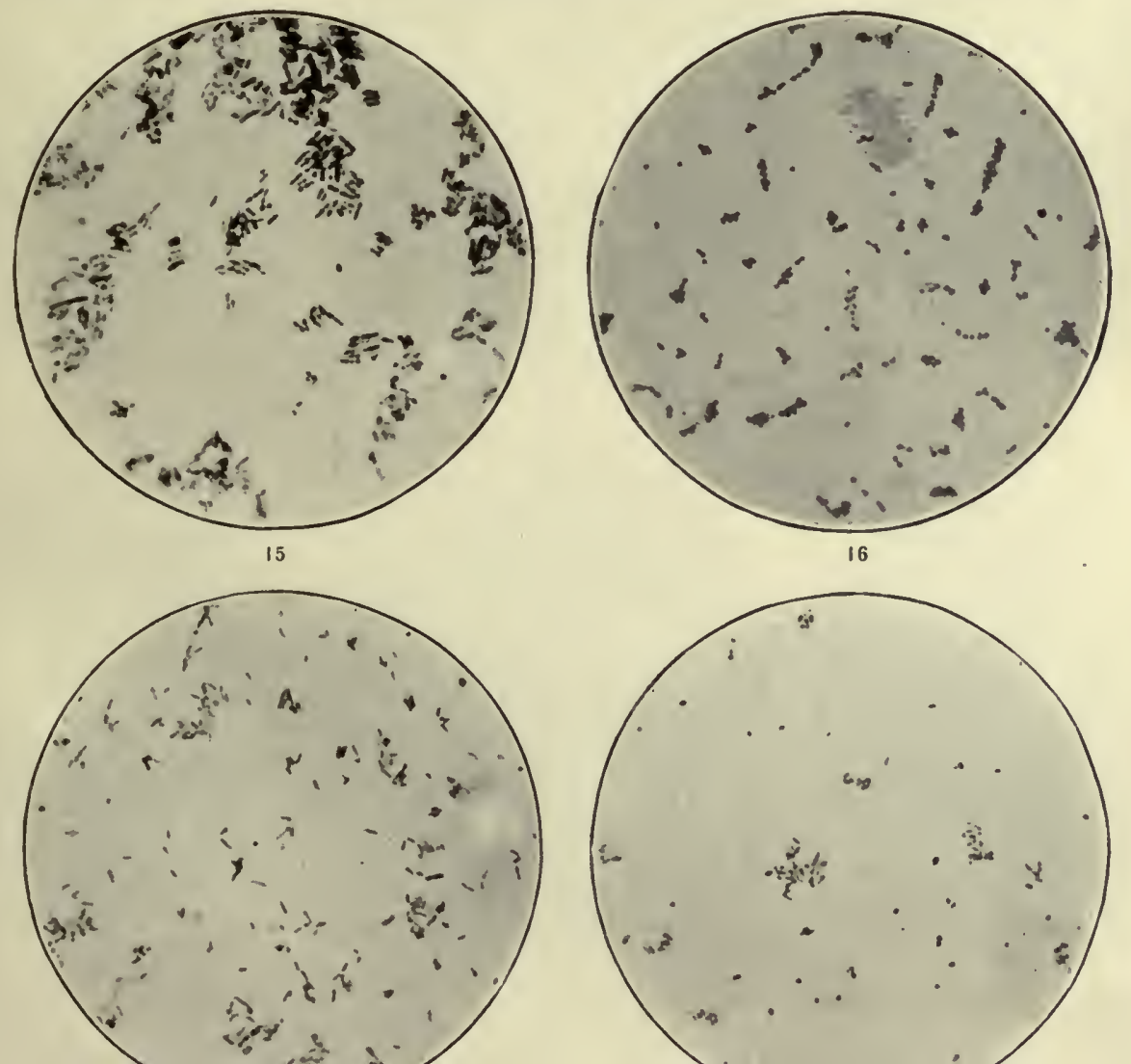

Plate 3
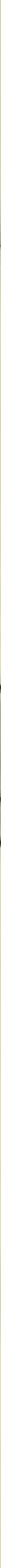



\section{VITA}

Frederick Eberson was born in New York City, February 10, 1892. He received his elementary and high school education in the city of Brooklyn, N. Y., and his first college training at the College of the City of New York, where he took the degree of Bachelor of Science in June, 1912. In October, 1912, he was appointed Research Assistant in the Department of Sanitary Science and Public Health at the Massachusetts Institute of Technology, Boston. Thence he matriculated under the Faculty of Medicine and Pure Science at Columbia University, specializing in Bacteriology and Biological Chemistry, and received his Master degree in June, 1914. In September, 1914, he was appointed Research Fellow and Assistant Instructor in the Department of Bacteriology and Hygiene at the Iowa State College, where he specialized in Bacteriology and Pathology and obtained his Master of Science degree in June, 1915. In September of the same year he was appointed Research Scholar under the tenure of a President's University Scholarship at Columbia University and continued work in the Department of Bacteriology until 1916, when he was appointed Research Bacteriologist to the North Manchurian Plague Prevention Service, Harbin, China, and was placed in charge of the Division of Bacteriology and Pathology. Toward the end of 1917 he was appointed to the staff of the Rockefeller Institute for Medical Research in the Department of Bacteriology and Pathology.

\section{Publications}

1912-The Effect of Drying on the Viability of Bacteria (with C. E. A. Winslow) Proceedings Soc. for Exp. Biol. and Medicine, May 5.

1915-A Bacteriologic Study of Secondary Invaders in Hog Cholera. Journal of Infectious Diseases, Vol. 17, No. 2.

Separation of the Antibody Fractions in Hog Cholera Serum. Journal of Infectious Diseases, Vol. 17, No. 2.

A Milk-Borne Paratyphoid Outbreak in Ames, Iowa (with M. Levine). Journal of Infectious Diseases, Vol. 18, No. 2.

1917-Plague Poisons and Virulence. Journal of Infectious Diseases, Vol. 20, No. 2; National Medical Journal of China, Vol. 3, No. 1.

Transmission of Pneumonic and Septicemic Plague among Marmots. Journal of Infectious Diseases, Vol. 20, No. 2; National Medical Journal of China, Vol. 3, No. 2: English Journal of Hygiene, Vol. 16, No. 1. 
Nature of Plagnc Proteotoxins. Journal of Infectious Discases, Vol. 21, No. 1; National Medical Jonrnal of China, Vol. 3, No. 1. 1918-Active Immunity to Systemic Plague Infection. Jourual of Infectious Diseases, Vol. 22, p. 62.

Experiments with Rosenow's Antipoliomyelitic Serum (with H. L. Amoss). Jourual of Experimental Medicine. Vol. 27, No. 2; Proc Soc. for Exp. Biol, and Medicine, April.

Pliysiological Study of the Choroid Plexus and Experimental Poliomyelitis (with Simon Flexuer and H. L. Amoss), Journal of Experimental Medicine, Vol. 27, No. 6.

Experiments with Nuzum and Willy's Antipoliomyelitic Sernim (with H. L. Amoss). Journal of Experimental Medicine, Vol. 28, No. 1.

Effect of Carbohydrate Concentration on Acid Production. Biochemical Bulletin (in press).

\section{Scientific Societies}

Society of American Bacteriologists.

American Association for the Advancement of Science.

National Medical Association of China.

Biochemical Society, Colımbia University. 











\section{DATE DUE SLIP}

UNIVERSITY OF CALIFORNIA, MEDICAL SCHOOL LIBRARY

THIS BOOK IS DUE ON THE LAST DATE STAMPED BELOW

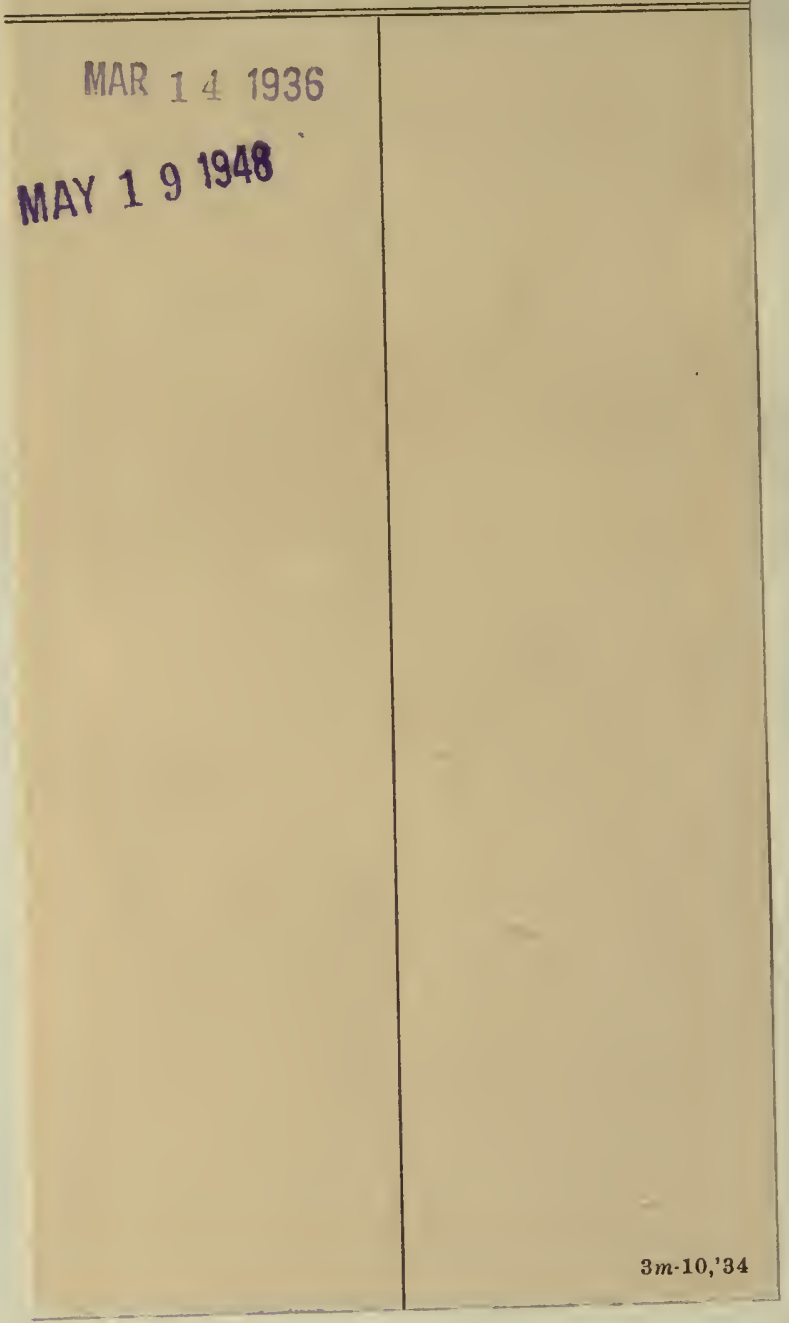


93754 
